\title{
əThe Impact of Indian Ocean Mean-State Biases in Climate Models on the Representation of the East African Short Rains
}

\author{
LINDA HIRONS \\ National Centre for Atmospheric Science, University of Reading, Reading, United Kingdom \\ ANDREW TURNER \\ Department of Meteorology, and National Centre for Atmospheric Science, University of Reading, \\ Reading, United Kingdom
}

(Manuscript received 27 November 2017, in final form 23 April 2018)

\begin{abstract}
The role of the Indian Ocean dipole (IOD) in controlling interannual variability in the East African short rains, from October to December, is examined in state-of-the-art models and in detail in one particular climate model. In observations, a wet short-rainy season is associated with the positive phase of the IOD and anomalous easterly low-level flow across the equatorial Indian Ocean. A model's ability to capture the teleconnection to the positive IOD is closely related to its representation of the mean state. During the shortrains season, the observed low-level wind in the equatorial Indian Ocean is westerly. However, half of the models analyzed exhibit mean-state easterlies across the entire basin. Specifically, those models that exhibit mean-state low-level equatorial easterlies in the Indian Ocean, rather than the observed westerlies, are unable to capture the latitudinal structure of moisture advection into East Africa during a positive IOD. Furthermore, the associated anomalous easterly surface wind stress causes upwelling in the eastern Indian Ocean. This upwelling draws up cool subsurface waters, enhancing the zonal sea surface temperature gradient between west and east and strengthening the positive IOD pattern, further amplifying the easterly wind stress. This positive Bjerknes coupled feedback is stronger in easterly mean-state models, resulting in a wetter East African short-rain precipitation bias in those models.
\end{abstract}

\section{Introduction}

Eastern Africa comprises the countries Tanzania, Burundi, Rwanda, Uganda, Kenya, Somalia, Ethiopia, South Sudan, Djibouti, and Eritrea. It is home to approximately 300 million people, many of whom live in rural areas and depend on rain-fed agriculture. The region is extremely vulnerable to interannual fluctuations in rainfall (Nicholson 2016). For example, two consecutive significantly below-average rainy seasons led to severe drought in 2010/11 that resulted in widespread food and water shortages (FEWS NET 2011). It is also home to some of the most flood-prone countries in Africa ( $\mathrm{Li}$ et al. 2016). When these extremes occur successively, such as the flooding following the

๑ Denotes content that is immediately available upon publication as open access.

Corresponding author: Linda Hirons, 1.c.hirons@reading.ac.uk
2011 drought, the impact is exacerbated considerably (Nicholson 2014). To help mitigate the impacts of future extreme events, it is vitally important to understand what controls the strong rainfall fluctuations over this region.

Most of eastern Africa has a bimodal distribution of rainfall characterized by two transition seasons from March to May (MAM), known as the "long" rains, and from October to December (OND), known as the "short" rains. This bimodal region, hereinafter referred to as East Africa (EA), is reasonably dry compared with other tropical land, with mean annual rainfall between 800 and $1200 \mathrm{~mm}$. While these transition seasons are modulated by the meridional migration of the intertropical convergence zone (ITCZ), Yang et al. (2015a) showed that fluctuations in near-surface moist static energy were crucial to enhancing rainfall over EA during the two rainy seasons.

Although the long rains are more reliable and provide a larger amount of rainfall to EA (Hastenrath 
et al. 1993), the short rains are more spatially coherent (Moron et al. 2007; Hastenrath et al. 2011) and exhibit more interannual variability (Camberlin and Wairoto 1997; Black et al. 2003; Hastenrath et al. 2011). Interannual variability in the short rains has been linked with remote forcing from the tropical Pacific (e.g., Nicholson and Kim 1997) and Indian (e.g., Bahaga et al. 2015) Oceans. However, the relative importance of these factors has been the subject of multiple studies, including a recent review (Nicholson 2017).

There is strong evidence that El Niño-Southern Oscillation (ENSO) in the tropical Pacific plays a crucial role in modulating the East African short rains (EASR) on interannual time scales (e.g., Bowden and Semazzi 2007). Specifically, the EASR significantly increase (decrease) during El Niño (La Niña) events (Dezfuli and Nicholson 2013; Hoell and Funk 2014). However, the links to ENSO vary regionally within EA and do not hold for all extreme years. For example, Nicholson and Selato (2000) showed that while most wet years were associated with El Niño events, most dry years showed no association with La Niña and, moreover, it has been speculated that the anticipated impact of ENSO in EA only materializes when corresponding warming/cooling of the Indian Ocean occurs concurrently (e.g., Goddard and Graham 1999; Hastenrath 2000).

The role of the Indian Ocean (IO) itself in modulating the EASR has been the subject of many studies, with authors concluding that interannual rainfall variability is strongly linked to the Indian Ocean dipole (IOD; e.g., Nakamura et al. 2011; Bahaga et al. 2015) and the associated strength of the overturning Walker cell (e.g., Mutai et al. 2012). The Walker cell is characterized by a strong eastward pressure gradient that results in lowlevel westerlies with opposing easterlies aloft, rising motion in the eastern IO, and large-scale subsidence in the west near the EA coastline. A positive IOD [warm sea surface temperatures (SSTs) in the western IO and cooler SSTs in the eastern IO; Saji et al. 1999] is associated with a weakening of this Walker cell in the IO, leading to enhanced rainfall over EA (Black et al. 2003; Nakamura et al. 2011), as anomalously easterly winds bring moisture to the region (Cai et al. 2013). Nicholson (2015) showed the intensity of this overturning cell in the equatorial IO, as measured by the strength of the low-level westerlies, was highly negatively correlated $(-0.74)$ with EA precipitation.

Studies directly comparing the impact of the Pacific and Indian Oceans have shown that, on interannual time scales, the EASR are more highly correlated with the IOD index (section 2d) than with SSTs in the eastern Pacific [a correlation of 0.80 compared to 0.64 in Liebmann et al. (2014); 0.61 compared to 0.49 in Nicholson (2015)]. This has led many authors to conclude that interannual variability in the EASR is more strongly modulated by the IOD and low-level equatorial IO westerlies than by the remote influence of ENSO (Bergonzini et al. 2004; Hastenrath et al. 2011; Nicholson 2015, 2017). Although ENSO and the IOD are not completely independent, this paper will focus on the role of the IO in modulating the EASR and will not examine ENSO further.

But how well do state-of-the-art models represent the EASR and the climate of the IO? Many current coupled global climate models (CGCMs) struggle, consistently overestimating the EASR (e.g., Yang et al. 2014) and the amplitude of the IOD (e.g., Cai and Cowan 2013). Both issues have persisted through generations of models.

CGCMs are also unable to correctly capture the seasonal cycle of rainfall over EA, resulting in underestimation of the long rains and significant overestimation of the EASR (Anyah and Qiu 2012; Yang et al. 2014). While these biases are slightly improved in atmosphere-only models (AGCMs; Yang et al. 2014), the wet bias is still present, suggesting this is not purely an issue with atmosphere-ocean coupling. Bollasina and Ming (2013) postulate that the existence of the wet bias in AGCMs is due to the models being too sensitive to meridional SST gradients in the western IO. Moreover, Yang et al. (2015b) suggest that other remote systematic biases in the tropics, such as the equatorial Pacific cold tongue and double ITCZ (Li and Xie 2014) or the weak Atlantic meridional overturning circulation (AMOC; Wang et al. 2014), may also play a role in the overestimation of the EASR.

The majority of CGCMs have SST biases in the IO that resemble a positive IOD ( $\mathrm{Li}$ et al. 2015). Cai and Cowan (2013) suggest this is due to the Bjerknes feedback being too strong over the equatorial IO. Specifically, they showed that models with the strongest thermocline-SST feedback also systematically exhibited the largest IOD amplitudes. Furthermore, the west-east slope of the equatorial thermocline in the IO controls the strength of the thermocline-SST feedback. Most models generate an overly deep thermocline in the western IO leading to an unrealistic thermocline tilt toward the east. This unrealistic thermocline structure is associated with excessive easterly winds and west-east SST gradient that further reinforce the tilt and lead to an excessive IOD amplitude (Cai and Cowan 2013). Li et al. (2015) suggest this can be traced to the weakerthan-observed southwest summer monsoon flow (e.g., Sperber et al. 2013), resulting in a warm SST bias-and overly deep thermocline-over the western equatorial IO leading, through the coupled Bjerknes feedback, to the positive IOD-like pattern seen in most models. 
TABLE 1. Description of the MetUM simulations

\begin{tabular}{llrc}
\hline \hline Simulation & \multicolumn{1}{c}{ Configuration } & Run length (years) & Reference \\
\hline GA6 & GA6 forced by observed SSTs (Reynolds et al. 2007) & 27 & Walters et al. (2011) \\
GC2 & GA6 coupled to ORCA025 ocean & 100 & Williams et al. (2015) \\
GA7 & GA7 forced by observed SSTs (Reynolds et al. 2007) & 27 & - \\
GC3 & GA7 coupled to ORCA025 ocean & 100 & - \\
\hline
\end{tabular}

While many studies have highlighted a wet bias in the EASR or discussed the influence of the IOD in controlling interannual rainfall variability over EA, very few have linked the two. This leads to several outstanding questions: (i) How is the wet bias over EA related to larger-scale mean-state biases in the IO, and are these consistent across models? (ii) What influence do such large-scale biases in the IO have on the interaction between the IOD and EASR? (iii) What is the role of ocean-atmosphere coupling? This study will address these questions by comparing teleconnections between the IOD and EASR in a range of coupled and atmosphereonly global climate models.

The remainder of this paper is structured as follows: A description of the model simulations and observational data is featured in section 2. Section 3 describes the analysis of simulations from the Met Office Unified Model (MetUM), while section 4 describes the analysis of CMIP5 models. Sections 5 and 6 contain the discussion and conclusions, respectively.

\section{Model, data, and methods}

\section{a. MetUM model simulations}

In this study, two atmosphere-only versions of the MetUM, Global Atmosphere 6.0 (GA6; Walters et al. 2011) and 7.0 (GA7), are compared with their fully coupled counterparts: Global Coupled 2.0 (GC2; Williams et al. 2015) and 3.0 (GC3), respectively. The global atmosphere (GA) models are driven by observed SSTs (Reynolds et al. 2007) and sea ice from the Atmospheric Model Intercomparison Project (AMIP) dataset (Taylor et al. 2012). The global coupled (GC) models comprise the GA coupled to the $0.25^{\circ}$ Nucleus for European Modelling of the Ocean (NEMO; Madec 2008) ocean model (known as ORCA025) via the Ocean Atmosphere Sea Ice Soil (OASIS) coupler (Valcke 2013). All MetUM simulations in this study are run at a horizontal resolution of $\mathrm{N} 216 ; 0.833^{\circ}$ longitude $\times$ $0.555^{\circ}$ latitude-approximately $60 \mathrm{~km}$ in the tropics. All MetUM simulations have 85 levels with a model lid at $85 \mathrm{~km}$. The GA simulations have 27 years (1982-2008) of available data from the AMIP period, whereas the GC simulations have 100 years of data (nominal years, 2013-2113 ${ }^{1}$ ). The GC simulations are fixed, present-day 100-yr free-running simulations with forcings set to values from 2000 (Experiment 2 in CMIP3; Williams et al. 2015). All available data have been analyzed for the EASR during OND. An overview of the MetUM simulations is given in Table 1.

GC2 was the global coupled configuration of the MetUM released in March 2014. GC3 is the most recent coupled configuration released in January 2016. The most noteworthy modifications in GA7/GC3 compared with $\mathrm{GA} 6 / \mathrm{GC} 2$ are to the physical parameterizations. These include 1) improved cloud and radiation processes; 2) revisions to the numerics of the convection scheme; 3) a new aerosol scheme; and 4) the introduction of a seamless stochastic physics package in the atmospheric model. For the purpose of this study, GA6/GC2 can be thought of as the old version and GA7/ GC3 the new version of the MetUM. These simulations will allow us to evaluate whether the MetUM is able to capture the teleconnection between the IOD and the EASR, and specifically whether SST biases introduced in the coupled model affect the fidelity of this teleconnection.

\section{b. CMIP and AMIP model simulations}

To test if the conclusions from comparing global versions of the MetUM are consistent across other models, the findings are compared with simulations from phase 5 of the Coupled Model Intercomparison Project (Taylor et al. 2012). Thirty years of data (1979-2008) from 30 AGCMs, using the AMIP experiment design, are compared to 27 years of data (1979-2005; the AMIP years) from 48 CGCMs, using the "historical" experiment. While it is not expected that the CMIP and AMIP years match equivalent years in observations, these experiments simulate present-day climate variability in the late twentieth and early twenty-first centuries and are both driven by realistic anthropogenic and natural forcings. If an ensemble of simulations is available, only the first ensemble member is used. For some

\footnotetext{
${ }^{1}$ The reader is reminded that this is a 100 -yr, free-running simulation and that these years do not correspond to observations.
} 
TABLE 2. Details of the CMIP and AMIP models used for analysis.

\begin{tabular}{|c|c|c|}
\hline Modeling center & Model names & Atmospheric horizontal resolution $\left({ }^{\circ}\right)$ \\
\hline $\mathrm{BCC}$ & BCC_CSM1.1, ${ }^{\mathrm{a}}$ BCC_CSM1.1 $(\mathrm{m})^{\mathrm{a}}$ & $2.8 \times 2.8,1.1 \times 1.1$ \\
\hline BNU & BNU-ESM ${ }^{\mathrm{a}}$ & $2.8 \times 2.8$ \\
\hline $\mathrm{CCCma}$ & CanAM $4,{ }^{\mathrm{b}}$ CanCM $4,{ }^{\mathrm{c}}$ CanESM $2^{\mathrm{c}}$ & $2.8 \times 2.8,2.8 \times 2.8,3.75 \times 3.7$ \\
\hline CMCC & CMCC-CESM, ${ }^{\mathrm{c}} \mathrm{CMCC}-\mathrm{CM},{ }^{\mathrm{a}} \mathrm{CMCC}-\mathrm{CMS}^{\mathrm{c}}$ & $3.75 \times 3.7,0.75 \times 0.7,1.875 \times 1.8$ \\
\hline CNRM-CERFACS & CNRM-CM5, ${ }^{\mathrm{a}}$ CNRM-CM5. $2^{\mathrm{c}}$ & $1.4 \times 1.4,1.4 \times 1.4$ \\
\hline CSIRO-BoM & ACCESS1.0, ${ }^{\mathrm{a}}$ ACCESS $1.3^{\mathrm{a}}$ & $1.875 \times 1.25,1.875 \times 1.25$ \\
\hline CSIRO-QCCCE & CSIRO Mk3.6.0 & $1.9 \times 1.9$ \\
\hline FIO & FIO-ESM ${ }^{\mathrm{c}}$ & $2.8 \times 2.8$ \\
\hline $\begin{array}{l}\text { Irish Centre for High-End } \\
\text { Computing (ICHEC) }\end{array}$ & EC-EARTH $^{\mathrm{a}}$ & $1.1 \times 1.1$ \\
\hline INM & INM-CM4.0 $0^{\mathrm{a}}$ & $2.0 \times 1.5$ \\
\hline IPSL & $\begin{array}{l}\text { IPSL-CM5A-LR, }{ }^{\mathrm{a}} \text { IPSL-CM5A-MR, } \\
\text { IPSL-CM5B-LR }{ }^{\mathrm{a}}\end{array}$ & $3.75 \times 1.875,2.5 \times 1.25,3.75 \times 1.875$ \\
\hline LASG-IAP & FGOALS-s $2^{\mathrm{b}}$ & $2.8 \times 1.7$ \\
\hline $\begin{array}{l}\text { LASG-Center for Earth System } \\
\text { Science (CESS) }\end{array}$ & FGOALS-g2 $^{\mathrm{a}}$ & $2.8 \times 2.8$ \\
\hline MIROC & MIROC4h, ${ }^{\mathrm{c}}$ MIROC5, ${ }^{\mathrm{a}}$ MIROC-ESM,${ }^{\mathrm{c}}$ & $0.56 \times 0.56,1.4 \times 1.4,2.8 \times 2.8$ \\
\hline - & MIROC-ESM-CHEM ${ }^{\mathrm{c}}$ & $2.8 \times 2.8$ \\
\hline $\mathrm{MOHC}$ & $\begin{array}{l}\text { HadCM3, }{ }^{\mathrm{c}} \text { HadGEM2-A, }{ }^{\mathrm{b}} \text { HadGEM2-CC, } \\
\text { HadGEM2-ES }\end{array}$ & $\begin{array}{l}3.7 \times 2.5,1.875 \times 1.25,1.875 \times 1.25 \\
1.875 \times 1.25\end{array}$ \\
\hline $\begin{array}{l}\text { Max Planck Institute for } \\
\text { Meteorology (MPI-M) }\end{array}$ & MPI-ESM-LR,${ }^{\mathrm{a}}$ MPI-ESM-MR, ${ }^{\mathrm{a}}$ MPI-ESM-P ${ }^{\mathrm{c}}$ & $1.9 \times 1.9,1.9 \times 1.9,1.9 \times 1.9$ \\
\hline MRI & $\begin{array}{l}\text { MRI-AGCM3.2H, }{ }^{\mathrm{b}} \text { MRI-AGCM3.2S, } \\
\text { MRI-CGCM3, }\end{array}$ & $0.6 \times 0.6,0.2 \times 0.2,1.1 \times 1.1$ \\
\hline - & MRI-ESM $1^{\mathrm{c}}$ & $1.1 \times 1.1$ \\
\hline NASA GISS & GISS-E2-H, ${ }^{\mathrm{c}}$ GISS-E2-H-CC, ${ }^{\mathrm{c}}$ GISS-E2-R, ${ }^{\mathrm{a}}$ & $2.5 \times 2.0,2.5 \times 2.0,2.5 \times 2.0$ \\
\hline- & GISS-E2-R-CC & $2.5 \times 2.0$ \\
\hline NCAR & $\mathrm{CCSM} 4^{\mathrm{a}}$ & $1.25 \times 0.9$ \\
\hline Norwegian Climate Centre (NCC) & NorESM1-M, ${ }^{\mathrm{a}}$ NorESM1-ME ${ }^{\mathrm{c}}$ & $2.5 \times 1.9,2.5 \times 1.9$ \\
\hline $\begin{array}{l}\text { National Institute of } \\
\text { Meteorological Research } \\
\text { (NIMR)-Korea Meteorological } \\
\text { Administration (KMA) }\end{array}$ & HadGEM2-AO ${ }^{c}$ & $1.875 \times 1.25$ \\
\hline NOAA/GFDL & $\begin{array}{l}\text { GFDL CM2.1, }{ }^{\mathrm{c}} \text { GFDL CM3, }{ }^{\mathrm{a}} \text { GFDL-ESM2G, }{ }^{\mathrm{c}} \\
\text { GFDL-ESM2M, }\end{array}$ & $2.5 \times 2.0,2.5 \times 2.0,2.5 \times 2.0,2.5 \times 2.0$ \\
\hline- & GFDL HiRAM-C $180,{ }^{\mathrm{b}}$ GFDL HiRAM-C $360^{\mathrm{b}}$ & $0.625 \times 0.5,0.3 \times 0.3$ \\
\hline NSF-DOE-NCAR & $\begin{array}{l}\text { CESM1(BGC) }{ }^{\mathrm{c}} \text { CESM1(CAM5), }{ }^{\mathrm{a}} \\
\text { CESM1(FASTCHEM), }{ }^{\mathrm{c}}\end{array}$ & $1.25 \times 0.9,1.25 \times 0.9,1.25 \times 0.9$ \\
\hline - & CESM1(WACCM) $)^{\mathrm{c}}$ & $1.25 \times 0.9$ \\
\hline
\end{tabular}

${ }^{\text {a }}$ AMIP and CMIP simulations available.

${ }^{\mathrm{b}}$ AMIP simulations available.

${ }^{\mathrm{c}}$ CMIP simulations available.

modeling groups, the AMIP and CMIP simulations are directly comparable pairs, ${ }^{2}$ while others provide several model versions. Hereinafter CMIP refers to the coupled models only and AMIP refers to the atmosphere-only experiments (details in Table 2).

\section{c. Observational datasets}

To validate the model simulations, observations of the real atmosphere are required. Reanalyzed zonal and meridional winds and specific humidity are taken from

\footnotetext{
${ }^{2}$ There are 22 AMIP-CMIP pairs.
}

the European Centre for Medium-Range Weather Forecasts (ECMWF) interim reanalysis (ERA-Interim; Dee et al. 2011), from 1979 to 2013. Reanalyzed zonal winds are also taken from the Twentieth Century Reanalysis Project (20C Reanalysis; Compo et al. 2011), from 1979 to 2014, and from the National Centers for Environmental Prediction (NCEP)-National Center for Atmospheric Research (NCAR) reanalysis (Kistler et al. 2001), from 1979 to 2017. Observed precipitation data are taken from the combined gauge and satellite Global Precipitation Climatology Project (GPCP) monthly precipitation dataset from 1979 to 2015 (Huffman et al. 2009), available at $2.5^{\circ} \times$ $2.5^{\circ}$ resolution. The observed SST data are taken from the 
Met Office Hadley Centre (MOHC) Sea Ice and Sea Surface Temperature dataset (HadISST) reconstruction of monthly mean SSTs, version 1 (Rayner et al. 2003), available on a $1^{\circ}$ grid from 1870 to 2009 .

\section{d. Methods}

To enable consistent comparison and statistical calculations, the monthly CMIP and AMIP data were bilinearly interpolated to the lowest common horizontal resolution of $3.75^{\circ}$ longitude $\times 3^{\circ}$ latitude. Where appropriate, the observations were also bilinearly interpolated to the same resolution for comparison. The multimodel mean (MMM) is obtained by taking the average of climate variables among the 30 AMIP and 48 CMIP models. It is recognized, however, that such an MMM approach has limitations because some CMIP models may share systematic biases due to shared expertise and model code (Abramowitz and Bishop 2015).

The IOD index is defined by calculating the SST gradient between the western equatorial IO $\left(10^{\circ} \mathrm{S}-10^{\circ} \mathrm{N}\right.$, $\left.50^{\circ}-70^{\circ} \mathrm{E}\right)$ and the southeastern IO $\left(10^{\circ} \mathrm{S}-0^{\circ} \mathrm{N}, 90^{\circ}-\right.$ $110^{\circ} \mathrm{E}$ ). Traditionally this is calculated as an anomalous SST gradient; however, to retain information about the underlying SST bias within each model, the absolute SST difference between west and east was used. To test how well this IOD index actually describes each model's IOD spatial pattern, empirical orthogonal function (EOF) analysis has been carried out on each model's detrended SST anomalies over the IO during OND (not shown). The majority of the models exhibit an IOD-like spatial pattern as their leading EOF, which explains $37.5 \%$ of the variance on average. The mean absolute correlation of the associated EOF1 time series with the IOD index for the 44 CMIP models with available data is $0.77 .^{3}$ This confirms that the IOD index introduced above is sufficient to describe each model's IOD mode of variability.

The latitudinal center of the Mascarene high (MH) is defined as the maximum in $850-\mathrm{hPa}$ geopotential height in the Africa-IO region $\left(45^{\circ} \mathrm{S}-15^{\circ} \mathrm{N}, 15^{\circ}-120^{\circ} \mathrm{E}\right)$. Similar to Manatsa et al. (2014), the eastern ridge of the MH is defined as the farthest east point of longitude along the defined latitude center that exceeds the geopotential height threshold of $1540 \mathrm{~m}$.

\section{SST teleconnection in the MetUM}

Previous studies have highlighted the role of equatorial Pacific and IO SSTs in controlling EASR variability

\footnotetext{
${ }^{3}$ Nineteen and 27 of the models exhibit an absolute correlation with the IOD index above 0.9 and 0.8 , respectively.
}

(e.g., Hoell and Funk 2014; Bahaga et al. 2015). Flood years in EA are associated with both El Niño conditions in the equatorial Pacific and a positive IOD, with relatively warmer SSTs in the western IO compared to the eastern IO (e.g., Dezfuli and Nicholson 2013). This is shown by correlating global SST with precipitation averaged over EA (Rowell 2013 and Fig. 1a). All MetUM simulations are able to capture the SST teleconnections to EA rainfall, showing strong positive correlations in the eastern Pacific and positive and negative correlations in the western and eastern IO, respectively. Compared to observations (Fig. 1a), the strength of the Pacific signal is best represented in the new versions of the MetUM (Figs. 1d,e; GA7 and GC3) and better confined to the equatorial and eastern coastal region in the coupled models (Figs. 1c,e; GC2 and GC3).

While all MetUM simulations capture a dipole pattern of correlation in the $\mathrm{IO}$, none are able to reproduce the clear IOD structure from observations. In the atmosphere-only models there is a dipole, but it is weak and not statistically significant across much of the basin (Figs. 1b,d). Coupling has a considerable impact on the IOD teleconnection, with a clear increase in strength and a significantly more coherent structure. However, the negative correlation in the eastern IO extends too far west along the equator in both $\mathrm{GC} 2$ and GC3 (Figs. 1c,e). This suggests that coupled model SST biases in GC2 and GC3 influence the structure of this teleconnection.

However, the fact that all MetUM model configurations are able to capture the basic features of the teleconnection between the EASR and IOD allows us to study it in more detail. The IO is a region where there are considerable differences between the MetUM simulations (Fig. 1); the remainder of this study will focus on the IO and how large-scale mean-state biases in this region influence the local response to rainfall during the EASR.

\section{a. MetUM OND mean state}

To analyze what controls variability in the EASR, it is important to understand the mean state on which these variations are occurring. Figure 2 shows the OND bias in precipitation, $\mathrm{SST}$, and $850-\mathrm{hPa}$ wind in all MetUM simulations compared with GPCP, HadISST, and ERA-Interim observations/reanalysis, respectively. The AGCMs are driven by AMIP-observed SSTs and so have very small SST biases compared with HadISST (Figs. 2a,c). However, the coupled models exhibit a mean-state SST bias in the IO that resembles the positive IOD (Figs. 2b,c). Associated with these SST biases, the CGCMs are too wet over the warm SSTs in the 
(a) HadISST and GPCP

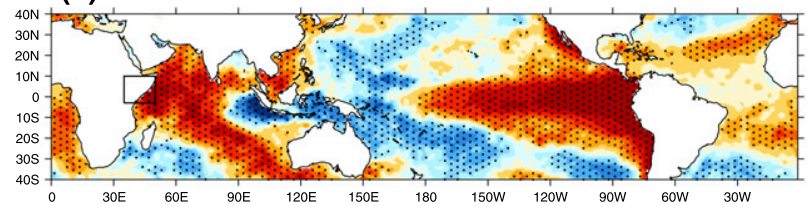

(b) GA6

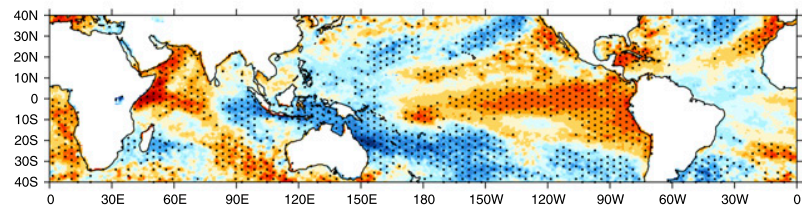

(d) GA7 (c) GC2

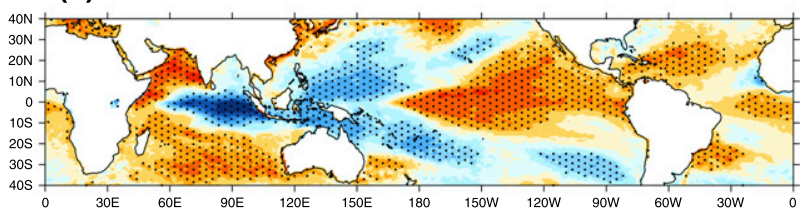

(e) GC3

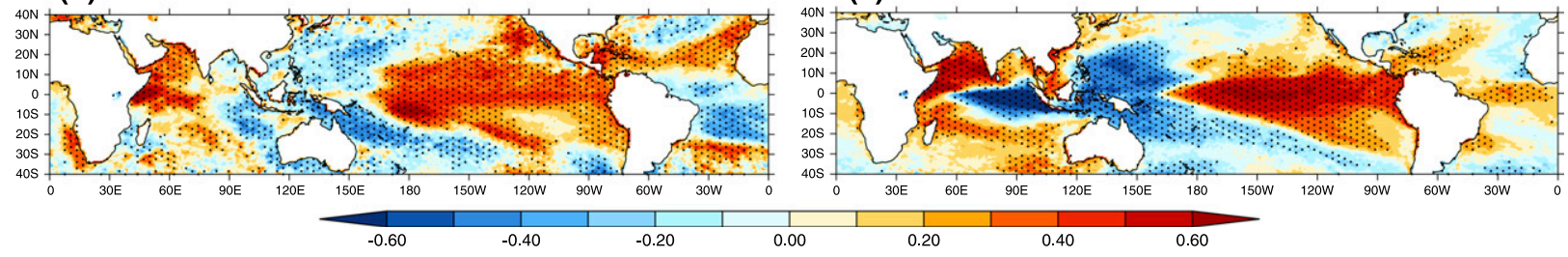

FIG. 1. (a) Correlations of observed OND rainfall from GPCP, averaged over EA [land points in the region $\left(3^{\circ} \mathrm{S}-10^{\circ} \mathrm{N}, 35^{\circ}-50^{\circ} \mathrm{E}\right)$; black square in (a)], against observed OND SSTs from HadISST, for the period 1979-2009. (b)-(e) As in (a), but for 27 years of GA6 and GA7 and 100 years of GC2 and GC3. Black stippling indicates the local rejection of the null hypothesis of zero correlation, at the 5\% significance level.

western IO and too dry over the cooler SSTs in the east. While these biases are slightly reduced in the new GC3 version, they are still present (Fig. 2d).

During OND, the ERA-Interim equatorial zonal wind at $850 \mathrm{hPa}$ is westerly across the IO with easterly off-equatorial trade winds between $10^{\circ}$ and $20^{\circ} \mathrm{N}$ and between $10^{\circ}$ and $20^{\circ} \mathrm{S}$. This is a very zonal pattern with a clear tripole structure in the IO (Fig. 3a). The AGCMs are able to capture the westerlies at the equator in the central IO, although they are weaker than observed (Figs. 3d,j). However, in the CGCMs the mean equatorial zonal wind in the IO is easterly (Figs. $3 \mathrm{~g}, \mathrm{~m}$ ), although this is slightly improved in GC3 compared with GC2.

The low-level wind will dynamically respond to the zonal SST gradient; therefore, it is not surprising that with the correct SST the mean-state wind is also closer to observations. Within CGCMs the atmosphere can respond to the coupled SST, which has a positive IOD bias (Figs. 2b,d), which leads to mean-state winds in the equatorial IO that are flowing in the wrong direction. This results in a positive Bjerknes coupled feedback where the anomalous easterly surface wind stress will excite upwelling of cooler subsurface water. The cooler water will further enhance the zonal SST gradient between the west and east and further amplify the wind stress (Cai et al. 2013).

We know that variability in the EASR is modulated by the IOD, but what will happen in a model whose mean state is already biased toward the very teleconnection pattern that drives the variability?

\section{b. MetUM positive IOD state}

To assess the representation of the IOD in the MetUM, composites have been made on years with a strong positive IOD pattern during OND. This is done by ranking all years in the respective datasets by the strength of the IOD index and compositing on the top $20 \%$ of years. A percentage of years-rather than a fixed number-was used as a method for comparing across datasets of different lengths. This results in 20 years contributing to the GC2 and GC3 composites, and only 7 and 5 years contributing to the observations and AGCMs, respectively.

\section{IMPACT OF POSITIVE IOD ON WINDS AND PRECIPITATION}

A positive IOD is associated with anomalous equatorial easterly flow across the IO Basin and wetter EA. In ERA-Interim, during a positive IOD, the anomalous easterly flow reduces the mean-state equatorial westerlies to near zero (Fig. 3b). The same can be seen in GA6 and GA7 (Figs. 3e,k). However, in GC2 and GC3 the anomalous easterly flow resulting from the positive IOD is acting on a mean state that is already easterly; therefore, the positive IOD in fact strengthens the existing easterly flow at the equator (Figs. 3h,n). The increasing strength of the near-surface wind in the 
(a) GA6

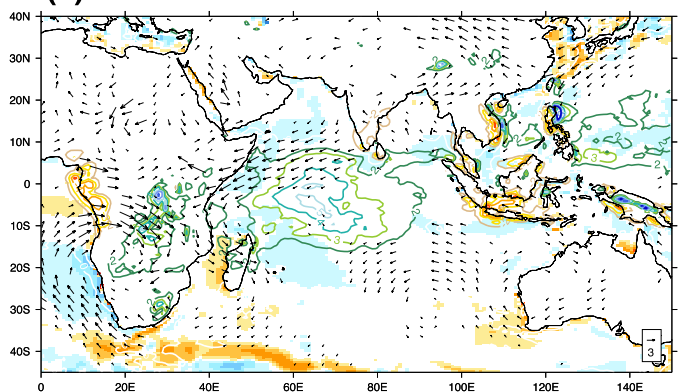

(c) GA7

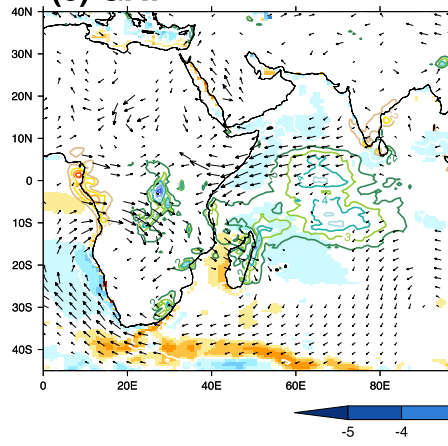

(b) GC2

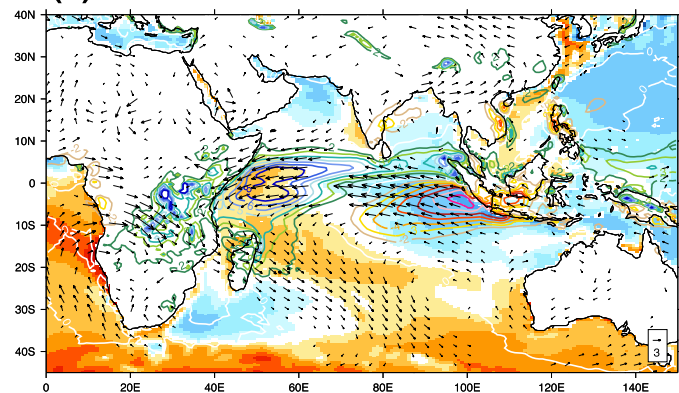

(d) GC3

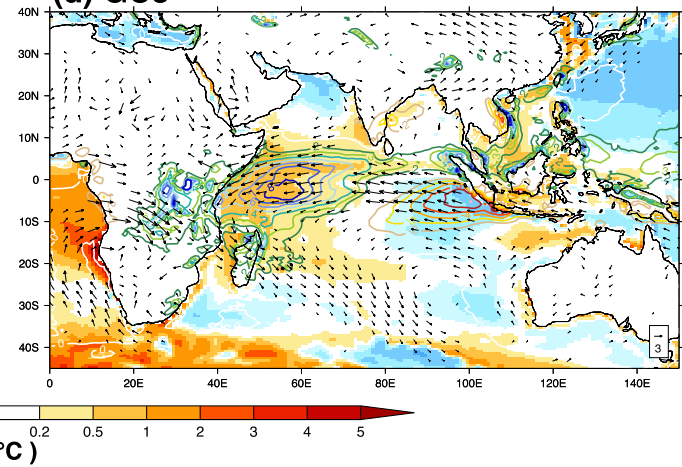

FIG. 2. Mean OND bias of SST (shading), 850-hPa winds (vectors), and precipitation (colored contours) from HadISST, ERA-Interim, and GPCP, respectively, for 27 years of (a) GA6 and (c) GA7, and 100 years of (b) GC2 and (d) GC3. Wet (dry) precipitation biases are shown by the green/blue (brown/red) contours every $\mathrm{mm} \mathrm{day}^{-1}$ starting at $2(-2) \mathrm{mm} \mathrm{day}^{-1}$.

IO is likely to enhance evaporation over the basin, resulting in potentially more moisture being advected toward EA.

South of the equator, the cool, dry southeasterly (SE) trade winds in the southern IO also weaken considerably in ERA-Interim during a positive IOD. This allows SSTs to remain warm in the western $\mathrm{IO}$, enhancing convection over the western IO and EA, resulting in wetter EASR.

The anomalous OND precipitation patterns during positive IOD events are compared in observations and MetUM simulations in Fig. 3 (right). As well as there being an IO dipole in SST, in observations there is also a west-east dipole in the response of OND precipitation to the positive IOD. Despite only having 7 years in the composite, GPCP shows a positive IOD pattern associated with anomalously wet conditions over EA/western IO and anomalously dry conditions over the eastern IO and Maritime Continent (Fig. 3c). The precipitation response in GA6 and GA7 has the same pattern; however, it is quite noisy (Figs. 3f,1). Although the coherence of this picture improves slightly with increased years in the composite, it is limited by the short simulation length of GA6 and GA7. The GC2 and GC3 composites look similar, both showing wet anomalies over central and $\mathrm{EA} /$ western IO and dry anomalies along the equatorial and southern IO and in the west Pacific warm pool (Figs. 3i,o). The precipitation signal is stronger in GC3 than in $\mathrm{GC} 2$, with rainfall anomalies over EA between 1 and $2 \mathrm{~mm}$ day $^{-1}$ compared with only $0.4-0.8 \mathrm{~mm}$ day $^{-1}$. However, the CGCM response to a positive IOD is not a west-east structure as in observations, but rather it has a north-south structure in the central IO. The extended anomalously dry region along the equator in GC2 and GC3 is consistent with the overextension of the negative SST anomalies shown in Figs. 1c and 1e. This is evidence of the coupled Bjerknes feedback having a detrimental impact in the CGCMs: the zonal SST gradient in the IO leads to excessive easterlies and upwelling in the eastern IO, which maintains the cooler SST in the central and eastern part of the basin and leads to a further amplification of the low-level easterly wind stress.

\section{c. Moisture advection into EA}

To study the means by which an IOD event perturbs the EASR, the advection of moisture into EA is examined. Using the same definition of positive IOD years, Fig. 4 shows composites of low-level $(850 \mathrm{hPa})$ moisture advection ( $u q$ and $v q$, where $u$ and $v$ are the eastward and northward components of the zonal wind and $q$ is the specific humidity). In ERA-Interim there is 
(a) ERA-I u850hPa

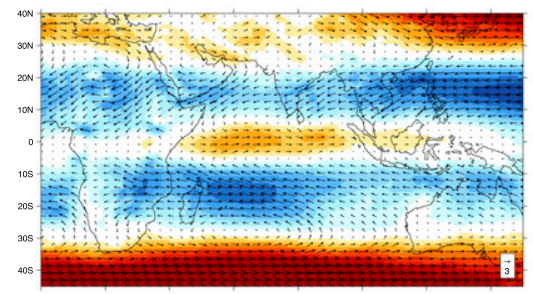

(d) GA6 $4850 \mathrm{hPa}$

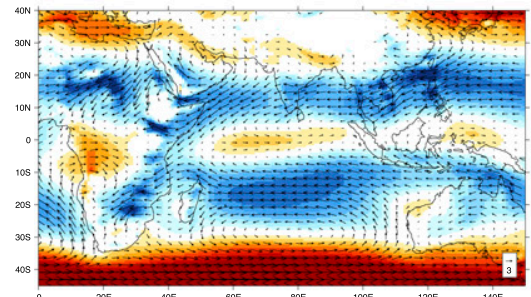

(g) GC2 u850hPa

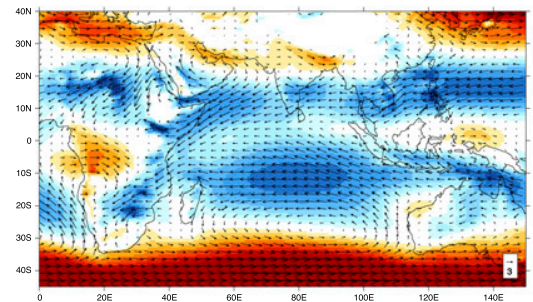

(j) GA7 u850hPa

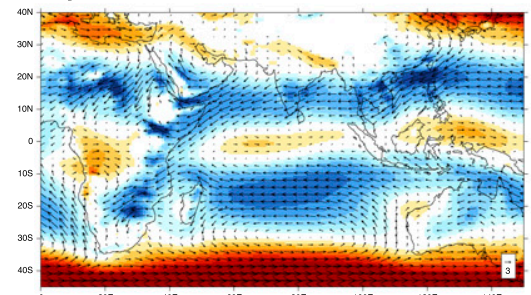

(m) GC3 u850hPa

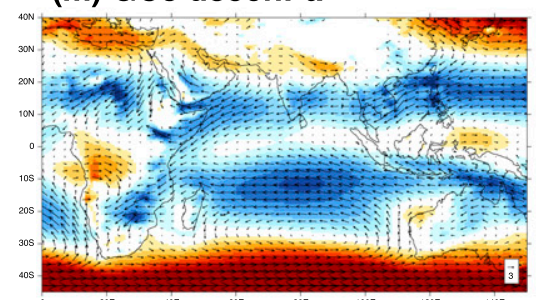

(b) ERA-I u850hPa +ve IOD

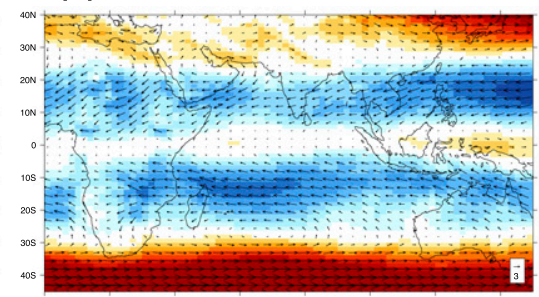

(e) GA6 u850hPa +ve IOD

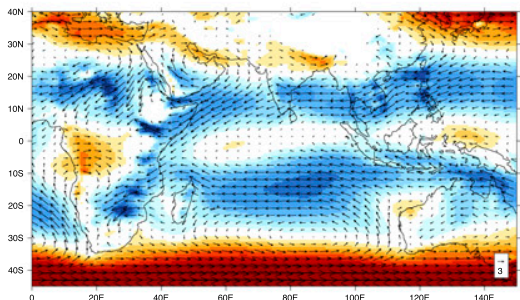

(h) GC2 u850hPa +ve IOD

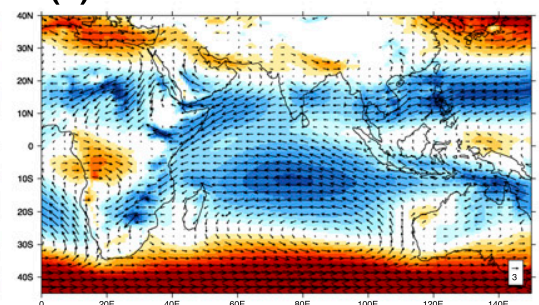

(k) GA7 u850hPa +ve IOD

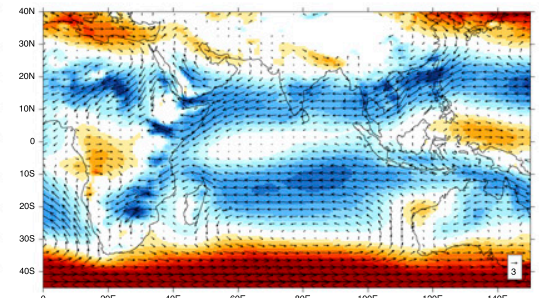

(n) GC3 u850hPa +ve IOD

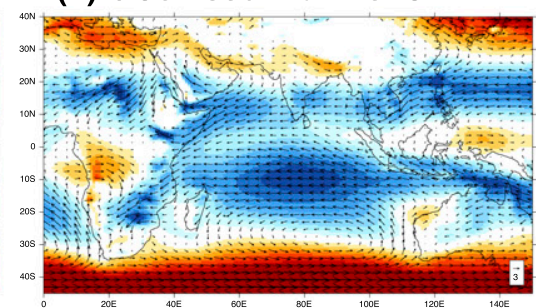

(c) GPCP precip +ve IOD

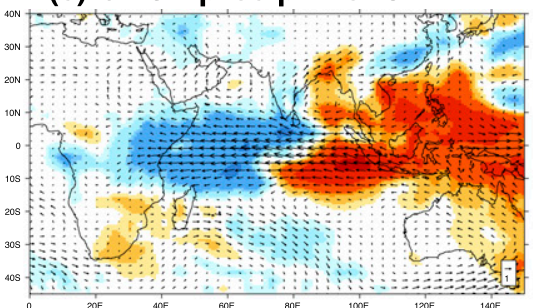

(f) GA6 precip + ve IOD

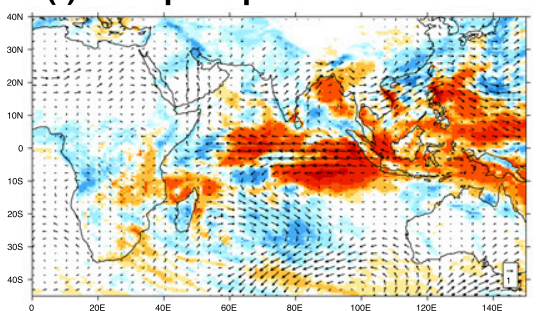

(i) GC2 precip + ve IOD

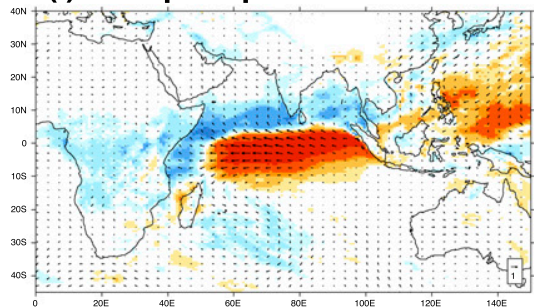

(I) GA7 precip +ve IOD

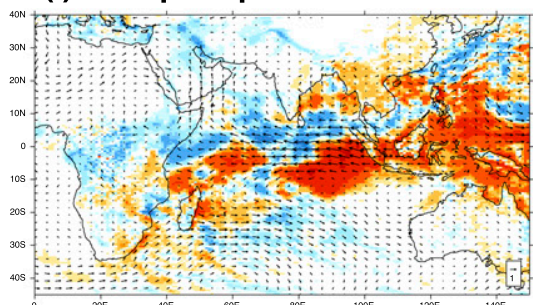

(o) GC3 precip +ve IOD

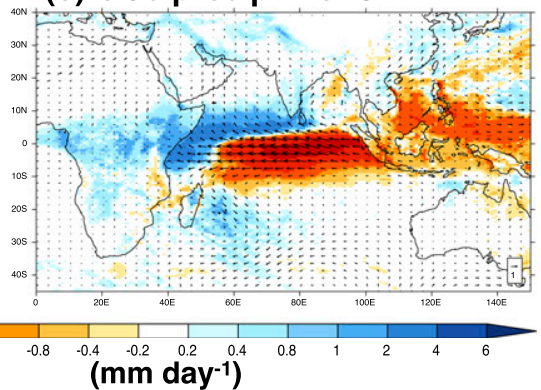

(m s s-1)

FIG. 3. (a) Mean OND 850-hPa wind (vectors; $u$ shading) from ERA-Interim. (d),(g),(j),(m) As in (a), but for GA6, GA7, GC2, and GC3, respectively. (b) Mean OND 850-hPa wind for positive IOD years from ERA-Interim (top 20\% of years after being ranked by the strength of the IOD index). (e),(h),(k),(n) As in (b), but for GA6, GA7, GC2, and GC3, respectively. (c) Anomalous OND precipitation and 850-hPa zonal wind for positive IOD years (positive IOD minus mean) from GPCP and ERA-Interim, respectively. (f),(i),(l),(o) As in (c), but for GA6, GA7, GC2, and GC3, respectively.

anomalous moisture advection into the EA region during positive IOD years (Fig. 4a). This advection of moisture extends across the entire equatorial IO Basin but splits as it enters the EA region, with clear peaks either side of the equator at $10^{\circ} \mathrm{N}$ and $10^{\circ} \mathrm{S}$ and a local mimimum (or "dip") at the equator (see also Fig. 5). The northern branch of moisture flux is stronger than the southern branch (Figs. 4a and 5a). 


\section{(a) ERA-Interim}

(b) GA6

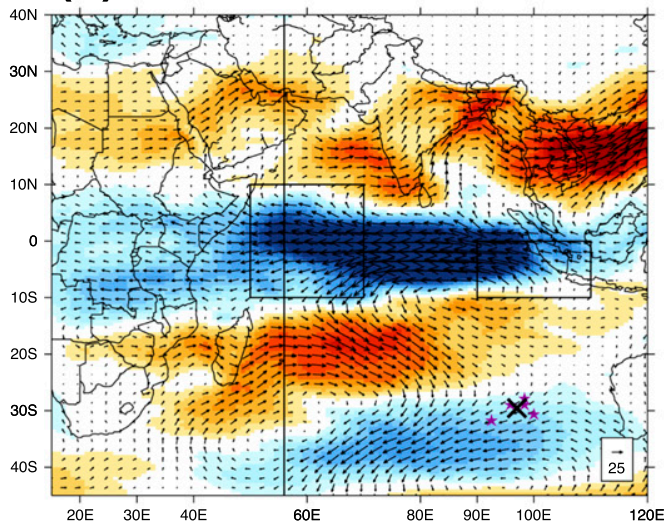

(d) GA7

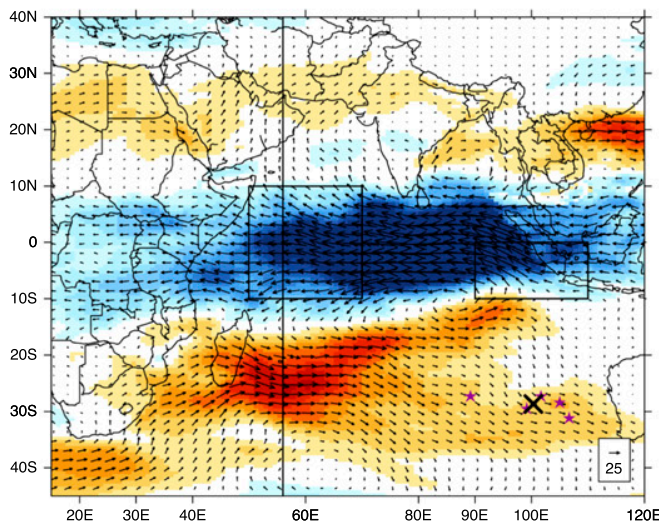

m.

$\stackrel{\circ}{\circ}$ (c) $\mathrm{GCC}$

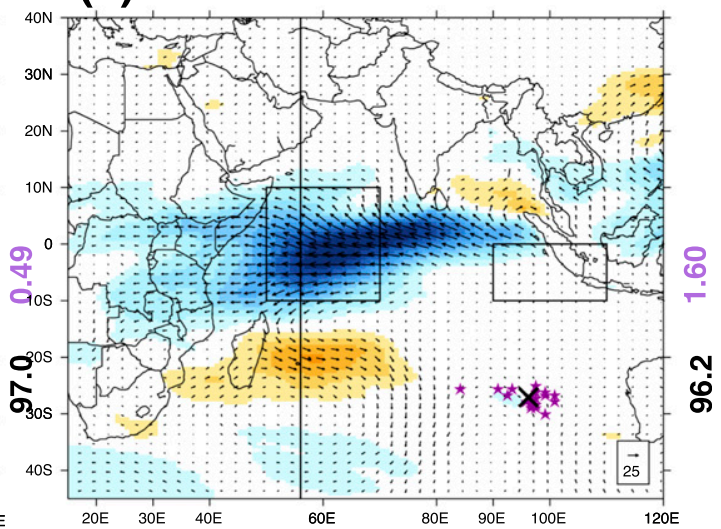

(e) GC3

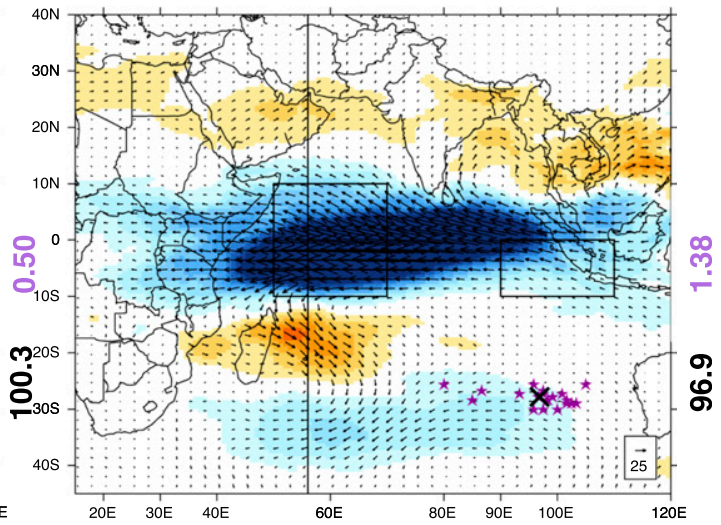

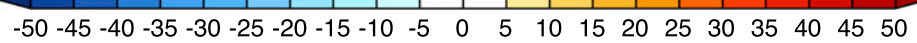

$\left(\mathrm{kg} \mathrm{m}^{-1} \mathrm{~s}^{-1}\right)$

FIG. 4. Composite anomaly of vertically integrated moisture flux (vectors) and magnitude of the $u q$ term (shading) from positive IOD years. Pink stars show the location of the eastern ridge of the MH in years of composite, and the large black cross shows the mean MH eastern ridge position for those years (mean MH value shown in black on the right). Black boxes show the IOD SST regions, with the mean IOD index value shown in purple (right). 


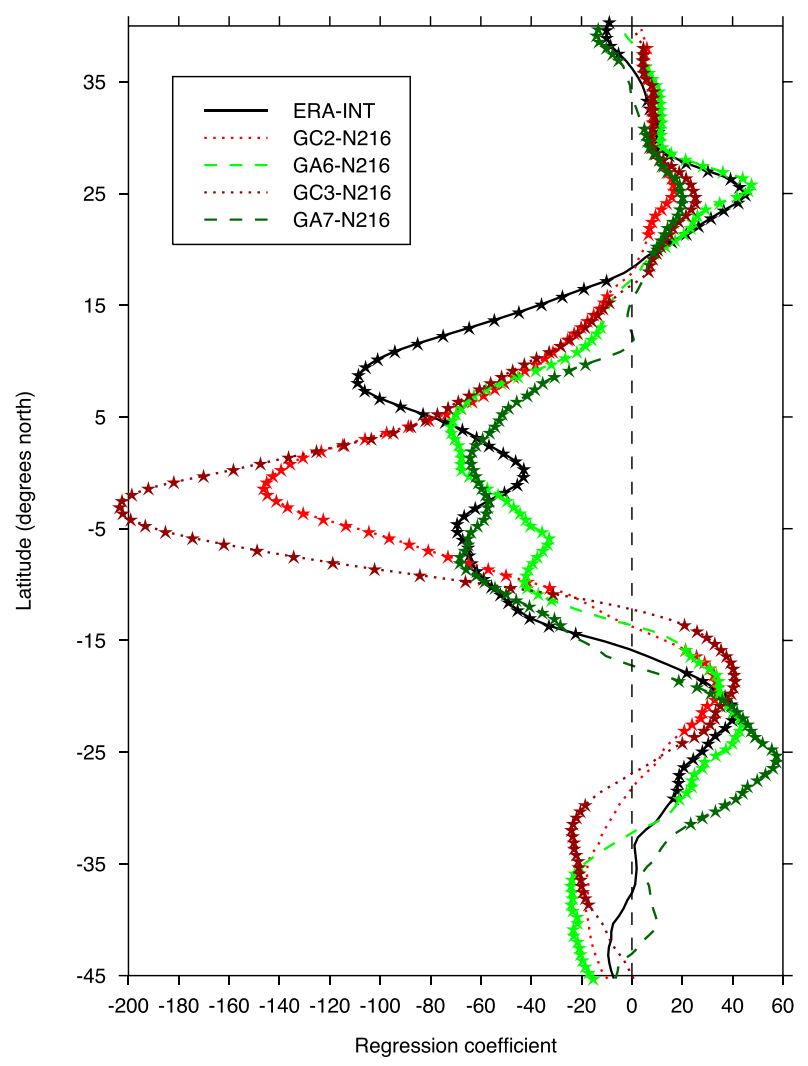

FIG. 5. Vertically integrated moisture flux $u q$ going along each latitude at $56^{\circ} \mathrm{E}$ regressed onto the IOD index. Green lines represent the AGCMs and red lines represent the CGCMs. Stars indicate where the regression coefficient is significant at the $5 \%$ level.

The pink stars on the diagram in Fig. 4 show the location of the eastern ridge of the $\mathrm{MH}$ during positive IOD years, with the mean shown by the larger black cross. During positive IOD years the $\mathrm{MH}$ eastern ridge is zonally displaced to the east compared with the mean observed (and model) position of approximately $92^{\circ} \mathrm{E}$. This agrees with Manatsa et al. (2014), who suggested flood (drought) years in EA were associated with the eastern ridge of the $\mathrm{MH}$ being zonally displaced to the east (west). ERA-Interim shows a weakening of the SE trades and increased rainfall over EA when there is a positive IOD (and the MH is displaced anomalously to the east; Figs. 3a-c and 4a).

All the MetUM simulations are able to capture largescale advection of moisture into EA during a positive IOD, and in all simulations this is associated with eastward displacement of the eastern ridge of the $\mathrm{MH}$ (Figs. 4b-e) and reduced SE trade winds (Figs. 3e,h,k,n). However, the MetUM simulations are unable to capture the equatorial "dip" in moisture advection in the western IO that is present in ERA-Interim (Fig. 4a) and show strong moisture advection toward equatorial EA
(Figs. 4b-e). The moisture advection is stronger and more broad in the newer versions of the MetUM (Figs. 4d,e), which more closely matches observations over the IO.

Figure 5 shows the regression of vertically integrated zonal moisture flux $u q$ going along each latitude at $56^{\circ} \mathrm{E}$ (the vertical line marked in Fig. 4) onto the IOD index. This provides a useful metric to determine the impact of the IOD on moisture fluxes advected toward EA. The strong peak of moisture being advected into the continent north of the equator and the equatorial dip are clear in the black ERA-Interim line. The CGCMs are unable to represent this feature, showing an erroneously strong peak just south of the equator, which is in fact worse in GC3 compared with GC2. This erroneous equatorial peak in the CGCMs can be explained by errors in the mean state: In the CGCMs the enhanced easterlies during a positive IOD are acting on top of an existing easterly mean state (Fig. 3). Therefore, rather than a positive IOD reducing the magnitude of the flow across the equatorial IO (as in ERA-Interim and the AGCMs), it in fact increases the existing easterly equatorial wind in the CGCMs, resulting in faster wind speeds, more equatorial evaporation in the basin, and therefore more moisture available to be advected toward EA at the equator. The AGCMs are better able to capture the latitudinal structure of moisture advection into EA during a positive IOD. This is likely due to having a better representation of the IO mean state with the correct SST distribution being prescribed and resultant low-level equatorial westerlies close to observations.

\section{d. Summary of the MetUM simulations}

Atmosphere-only (GA6, GA7) MetUM simulations have been compared with their fully coupled counterparts $(\mathrm{GC} 2, \mathrm{GC} 3)$ to assess their ability to capture the observed teleconnection between the IOD and interannual variability in the EASR. In observations, wet EASR are associated with a positive IOD, a more easterly low-level flow across the equatorial IO (the eastern ridge of the $\mathrm{MH}$ being zonally displaced to the east), and a weakening of the cool, dry SE trade winds in the southern IO. Many of these features are better captured by the MetUM AGCMs than the CGCMs. This is because the AGCMs have a closer-to-observed IO mean state. The MetUM AGCMs have the correct distribution of SSTs and the mean-state low-level equatorial winds flowing in the correct direction (eastward) in the IO. This means that in the MetUM AGCMs, during a positive IOD, the easterly anomalies reduce mean-state westerlies, reducing the absolute wind strength across the equatorial IO. However, in the 
MetUM CGCMs, there is an SST bias that already resembles the positive IOD, and the associated easterly anomalies strengthen the existing easterlies, resulting in stronger overall equatorial low-level wind. This results in the MetUM CGCMs being unable to capture the observed latitudinal structure of moisture advection into the EA region during the positive IOD. The AGCMs are better able to capture the observed equatorial dip in moisture advection into EA during wet years (Fig. 5). This analysis has therefore shown that mean-state biases in SST and zonal wind in the IO result in the MetUM being unable to capture all the observed features of this teleconnection to the EASR.

\section{Extension to CMIP ensemble}

To test if similar mean-state biases affect the IODEASR teleconnection in other atmosphere-only and coupled models, this analysis has been extended to the CMIP and AMIP models (Table 2).

\section{a. Mean state}

The OND mean state of 30 atmosphere-only models (AMIP; Table 2) and 48 atmosphere-ocean coupled models (CMIP; Table 2) are compared with ERAInterim and GPCP data. Figures $6 c$ and $6 d$ show that the AMIP and CMIP MMMs capture the observed structure of low-level equatorial westerlies and offequatorial easterlies across the IO. The pattern correlation compared with ERA-Interim is calculated for the larger box $\left(30^{\circ} \mathrm{S}-25^{\circ} \mathrm{N}, 40^{\circ}-105^{\circ} \mathrm{E}\right)$ in Fig. $6 \mathrm{a}$, chosen to represent the large-scale pattern across the entire IO Basin. This pattern is well captured by AMIP and CMIP with pattern correlations of 0.91 and 0.91 , respectively. The coupled models with the lowest and highest pattern correlations are shown in Figs. 6e and 6f. MRI-CGCM3 (black star in Fig. 6b) shows a similar large-scale equatorial IO structure to that of GC2 and GC3 (Fig. 3), with equatorial easterlies in the IO rather than westerlies, resulting in a poor pattern correlation of 0.54 . The CGCM with the highest ${ }^{4}$ pattern correlation is CESM1(CAM5) (black diamond in Fig. 6b), with a correlation of 0.94. It is clear that this model is able to capture stronger, broader equatorial westerlies in the IO (Fig. 6f). In fact, it slightly overestimates the strength of the westerlies compared to ERA-Interim.

For all 78 models (30 AMIP and 48 CMIP), the equatorial 850 -hPa zonal wind has been averaged over

\footnotetext{
${ }^{4}$ This excludes EC-EARTH, which has a pattern correlation of 0.95 but was disregarded because it is compared with the reanalysis product from the same center.
}

the smaller box $\left(5^{\circ} \mathrm{S}-5^{\circ} \mathrm{N}, 50-100^{\circ} \mathrm{E}\right)$ shown in Fig. $6 \mathrm{a}$. This box was chosen to capture the observed equatorial westerlies and results in positive values of $1.29,1.64$, and $2.48 \mathrm{~m} \mathrm{~s}^{-1}$ for ERA-Interim, NCEP-NCAR reanalysis, and Twentieth Century Reanalysis, respectively (black, dark gray, and light gray bars in Fig. 6b). Both AMIP and CMIP MMMs exhibit mean westerlies in the central equatorial IO (Figs. 6c,d); however, they are not meridionally broad enough, so when averaged over the equatorial box defined by observations, their values are -0.201 and $0.003 \mathrm{~m} \mathrm{~s}^{-1}$, respectively (black unfilled triangles in Fig. 6b). In fact, when all models are stratified by this measure of area-averaged $850-\mathrm{hPa}$ zonal wind, half (39 of the 78) of the models actually have mean easterlies in the equatorial IO (Fig. 6b), similar to the easterlies seen in coupled versions of the MetUM (GC2 and GC3 in Figs. 3g,m).

For the MetUM, there was a clear distinction between AGCMs and CGCMs in terms of the direction of the mean low-level equatorial zonal wind, with the CGCMs being easterly and the AGCMs being westerly, as in observations. However, it is clear from Fig. $6 \mathrm{~b}$ that the AMIP and CMIP models are distributed evenly between westerly and easterly flow in the equatorial IO, with an easterly-to-westerly ratio of $14: 16$ and $25: 23$ for the AMIP and CMIP models, respectively. While there are many modeling factors that could affect this IO meanstate bias (e.g., choice of physical parameterizations, vertical and horizontal resolution), the presence of an interactive ocean does not appear to be the dominant one. However, coupling to an interactive ocean is likely to exacerbate an existing bias through a positive Bjerknes-type coupled feedback.

Figure 7 investigates the influence of the mean equatorial zonal wind on local precipitation over EA. For each model and the MMMs, the pattern correlation compared with GPCP is calculated for the box shown in Fig. $7 \mathrm{a}\left(15^{\circ} \mathrm{S}-15^{\circ} \mathrm{N}, 30-60^{\circ} \mathrm{E}\right)$, chosen to represent the local precipitation over EA and the coastal region. The OND precipitation bias for AMIP and CMIP MMMs, as well as the highest (NASA GISS-E2-H-CC; black star in Fig. 7b) and lowest [BCC_CSM1.1(m), herein denoted as bcc-csm1-1-m; black diamond in Fig. 7b] pattern correlation models are shown in Figs. 7c-f. In agreement with previous studies (Yang et al. 2015a), the CMIP and AMIP models show wet biases over the EA region during OND (Fig. 7b). This bias is significantly smaller in the AMIP MMM compared with the CMIP MMM (1.47 compared with $1.93 \mathrm{~mm}$ day $^{-1}$; Fig. $7 \mathrm{~b}$ ); the AMIP MMM also shows a higher pattern correlation than the CMIP MMM (0.91 and 0.79; Figs. 7c,d).

Figure $7 \mathrm{~b}$ shows the area-averaged EA precipitation bias for each model versus that model's mean low-level 
(a) ERA-Interim

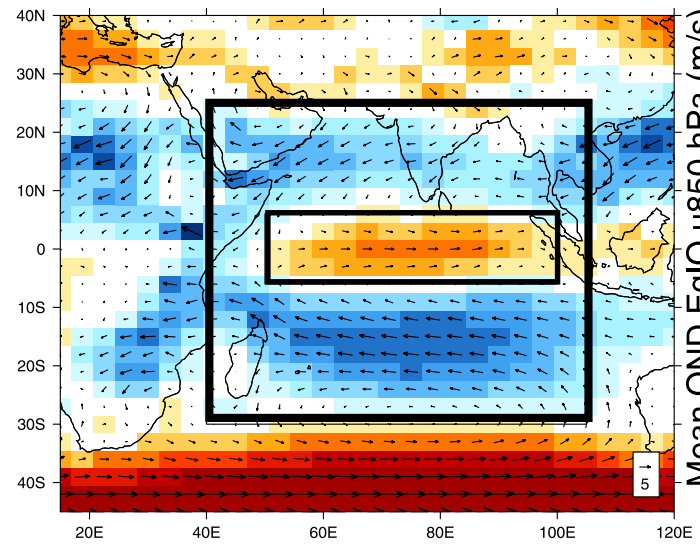

(c) AMIP MMM

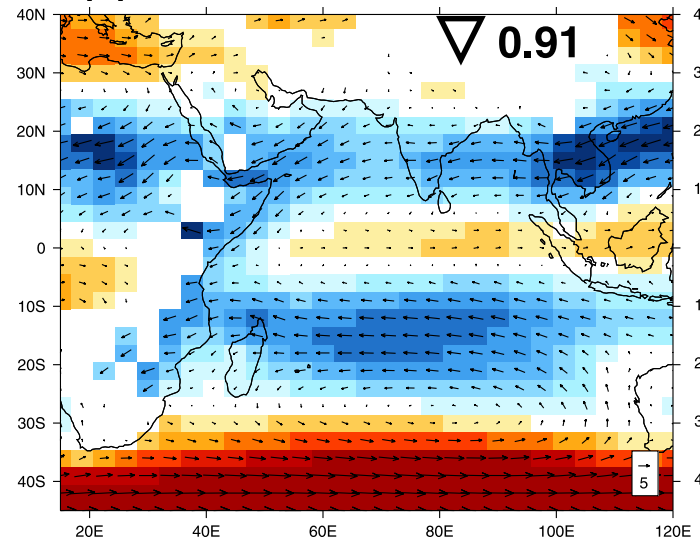

(e) MRI-CGCM3

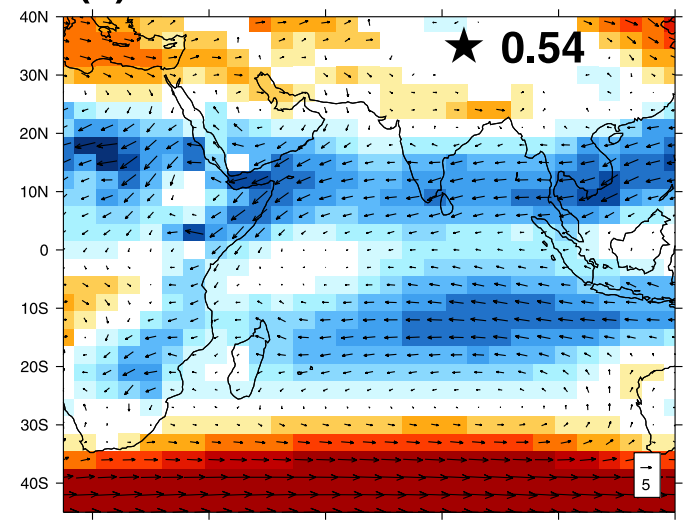

(b) Stratified by OND EqIO u850

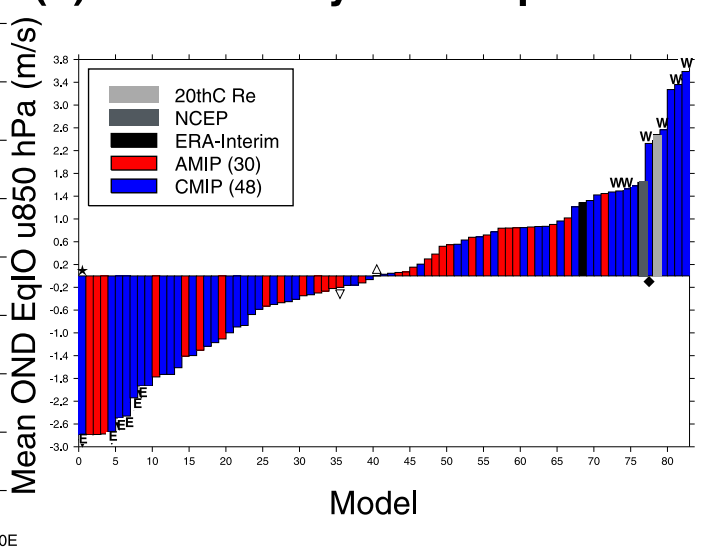

(d) CMIP MMM

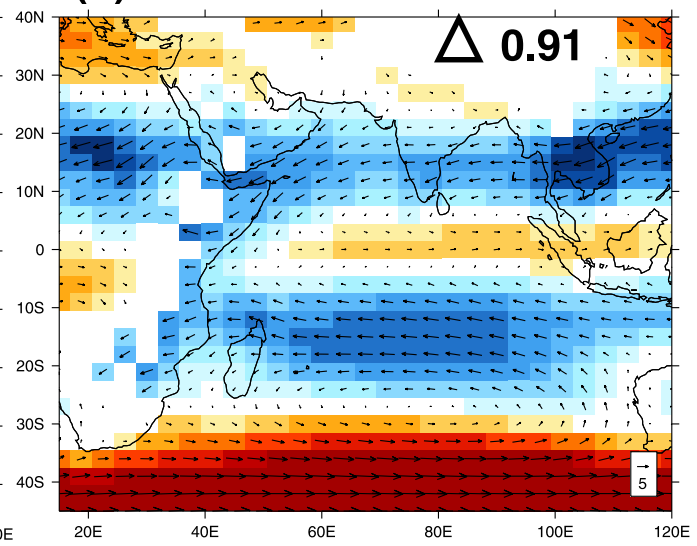

(f) CESM1-CAM5

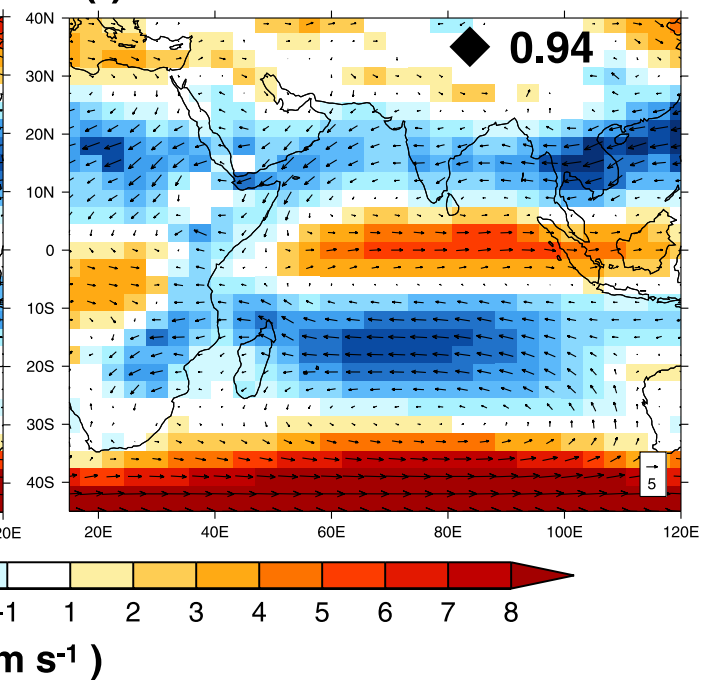

FIG. 6. (a) Mean OND 850-hPa wind (vectors; $u$ shading) from ERA-Interim. (b) Thirty AMIP (red) and 48 CMIP (blue) models stratified by the area-averaged 850-hPa zonal wind in the equatorial IO [small box in (a)]. Easterly and westerly models used for the composite analysis are labeled in (b) with letters $\mathrm{E}$ and $\mathrm{W}$, respectively. (c)-(f) As in (a), but for AMIP MMM, CMIP MMM, MRI-CGCM3, and CESM1(CAM5), respectively. The pattern correlations with ERA-Interim, calculated over the larger box in (a), are shown in the top right-hand corner of each panel along with the symbol used to identify this model in (b). (e) and (f) show the models with the lowest and highest pattern correlations with ERA-Interim. 
(a) GPCP

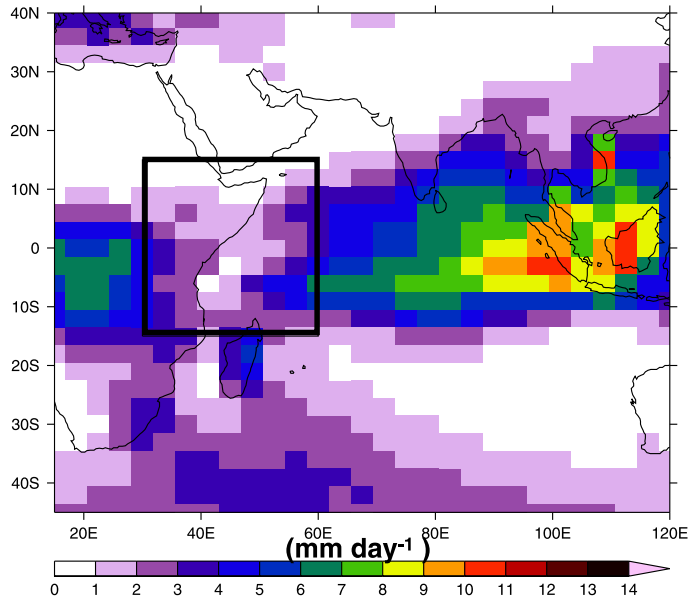

(c) AMIP MMM

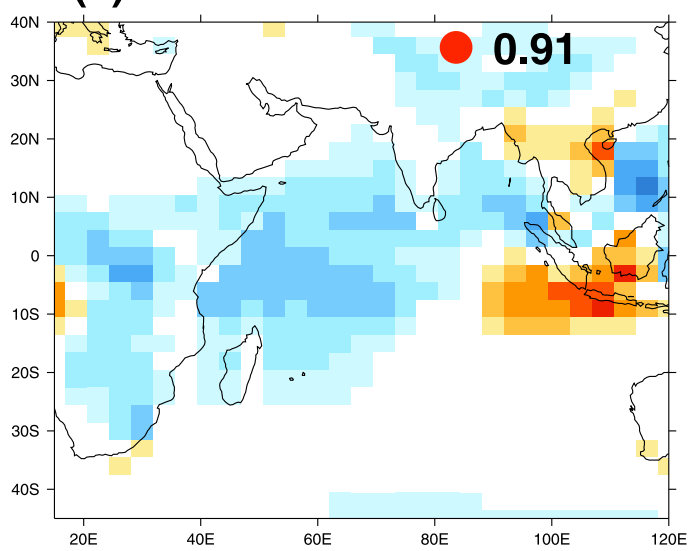

(e) NASA-GISS-E2-H-CC

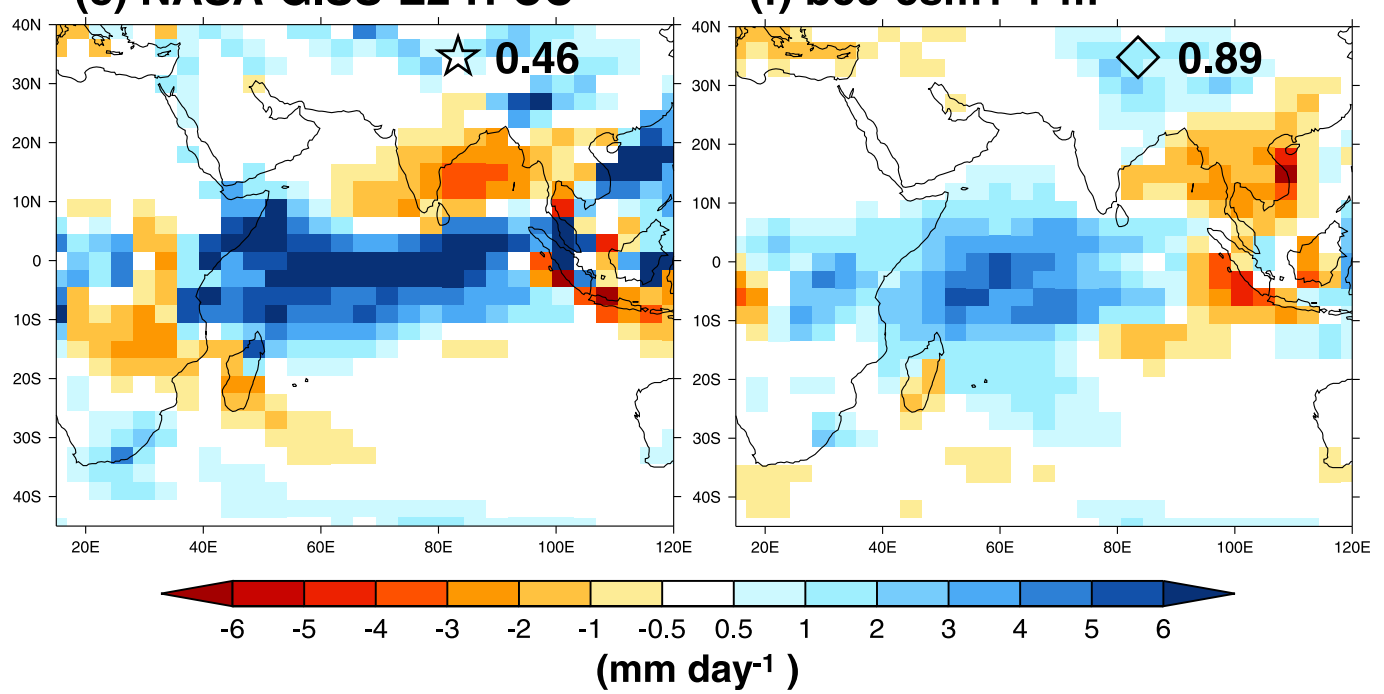

FIG. 7. (a) Mean OND precipitation from GPCP. (b) EA OND precipitation bias over land vs mean equatorial IO 850-hPa wind for 30 AMIP (red) and 48 CMIP (blue) models. Easterly and westerly models used for the composite analysis are labeled with letters E and W, respectively. (c)-(f) OND precipitation bias compared with GPCP for AMIP MMM, CMIP MMM, NASA GISS-E2-H-CC, and bcc-csm1-1-m, respectively. The pattern correlations with GPCP, calculated over the box in (a), are shown in the top right-hand corner of each panel along with the symbol used to identify this model in (b). Note the low and high pattern correlation models shown in Figs. $6 \mathrm{e}$ and $6 \mathrm{f}$ differ from those models shown here in (e) and (f).

(b) EqIO u850 vs EA precip bias

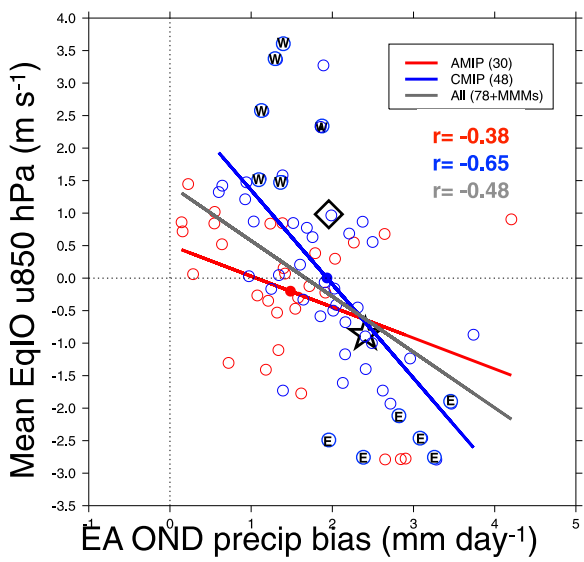

(d) CMIP MMM

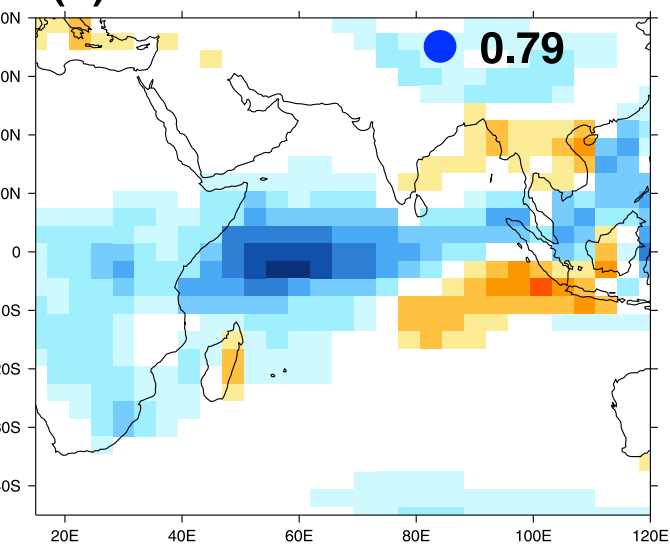

(f) bcc-csm1-1-m

\section{(1)}


TABLE 3. CMIP models used for compositing on those models with a strong easterly mean state in the EqIO (top half) and those with a strong westerly mean state (bottom half).

\begin{tabular}{llcr}
\hline \hline Modeling center & \multicolumn{1}{c}{ Model names } & EqIO 850-hPa & EA precipitation bias \\
\hline MRI & MRI-CGCM3 & -2.79 & 3.28 \\
CMCC & CMCC-CMS & -2.74 & 2.38 \\
CMCC & CMCC-CM & -2.50 & 1.96 \\
MRI & MRI-ESM1 & -2.46 & 3.10 \\
MOHC & HadGEM2-CC & -2.14 & 2.83 \\
CSIRO-BoM & ACCESS1.3 & -1.93 & 3.47 \\
Easterly mean & & -2.43 & 2.84 \\
CCCma & CanESM2 & 3.59 & 1.38 \\
NSF-DOE-NCAR & CESM1(WACCM) & 1.32 \\
ICHEC & EC-EARTH & 3.36 & 1.15 \\
NSF-DOE-NCAR & CESM1(CAM5) & 1.86 \\
CSIRO-QCCCE & CSIRO Mk3.6.0 & 2.57 & 1.12 \\
MIROC & MIROC-ESM-CHEM & 2.33 & 1.39 \\
Westerly mean & & 1.53 & 1.37 \\
\hline
\end{tabular}

equatorial IO winds. The models with a more easterly mean state in the equatorial IO have higher EA precipitation biases than those with a more westerly mean state. This negative relationship is shown in Fig. $7 \mathrm{~b}$ for all models (gray line; $r=-0.48$ ) as well as the CMIP (blue line; $r=-0.65$ ) and AMIP (red line; $r=-0.38$ ) models separately. This confirms the hypothesis that the wet bias is significantly worse in GCMs that have a more easterly mean low-level flow in the equatorial IO.

\section{b. Easterly mean-state versus westerly mean-state models}

Given the clear evidence that EA precipitation biases are worse in GCMs with a more easterly low-level mean state in the equatorial IO (EqIO), composite analysis has been carried out comparing the six most easterly and six most westerly ${ }^{5}$ CMIP models. There is no clear distinction in Fig. $6 \mathrm{~b}$ between the behavior of CMIP versus AMIP models; therefore, for simplicity, only CMIP models have been considered for this composite analysis. The models used are marked in Figs. $6 \mathrm{~b}$ and $7 \mathrm{~b}$ by the labels "E" and "W" (Table 3).

Figures $8 \mathrm{a}-\mathrm{e}$ shows the composite difference between six easterly (averaging $-2.43 \mathrm{~m} \mathrm{~s}^{-1}$ in the equatorial IO; Table 3) and six westerly (averaging $2.48 \mathrm{~m} \mathrm{~s}^{-1}$ in the equatorial IO; Table 3) models for near-surface zonal wind, 200-hPa zonal wind, precipitation, 850-hPa moisture flux $(u q, v q)$, and SST. The low-level zonal wind bias in the equatorial IO is not confined to $850 \mathrm{hPa}$ but extends to the surface, with easterly models unable to

\footnotetext{
${ }^{5}$ The six most westerly models used are actually ranked $1,2,4,5$, 7 , and 8 because all the data for all the required variables were not available from models ranked 3 and 6 . See labels "E" and "W" on Figs. $6 \mathrm{~b}$ and $7 \mathrm{~b}$ and model details in Table 3.
}

capture the surface westerlies (Fig. 8a). In fact, the entire Walker circulation is affected-in ERA-Interim, upper-level equatorial easterlies complete the overturning Walker cell. These easterlies are weaker than observed in westerly models but weaker still in easterly models. Figure $8 \mathrm{~b}$ shows the easterly models exhibit increased westerly flow throughout much of the tropics at upper levels. The difference in the SST resembles a positive IOD pattern, with the easterly models having warmer SSTs in the west and southern IO and cooler SSTs in the east of the basin (Fig. 8e). This is consistent with the findings for the MetUM simulations: the SST bias resembled this positive IOD pattern and resulted in easterly flow in the equatorial IO in the coupled runs (GC2 and GC3; Figs. 2b,d and 3g,m). The corresponding pattern in precipitation (Fig. 8c) shows that the easterly models are wetter over the western IO and EA and drier over the eastern IO.

Figure $8 \mathrm{f}$ investigates the impact of the mean-state biases in the IO on thermocline gradients across the IO Basin. The $20^{\circ} \mathrm{C}$ isotherm depth, which is used as a proxy for thermocline depth, has been calculated over equatorial boxes in the western $\left(5^{\circ} \mathrm{S}-5^{\circ} \mathrm{N}, 45^{\circ}-65^{\circ} \mathrm{E}\right)$ and eastern $\left(5^{\circ} \mathrm{S}-5^{\circ} \mathrm{N}, 85^{\circ}-105^{\circ} \mathrm{E}\right)$ IO (see insert of Fig. 8f) and plotted against each other to give an indication of the thermocline tilt across the IO Basin. The mean difference in $20^{\circ} \mathrm{C}$ isotherm depth between the western and eastern IO is also shown in the map insert of Fig. 8f. Generally in easterly models (red dots in Fig. 8f), the thermocline is deeper in the western IO compared to the eastern IO, giving a positive average difference in depth of $16.98 \mathrm{~m}$. The opposite is true of westerly models (green dots in Fig. 8f), with the eastern IO having a deeper thermocline than the west and a negative average difference of $-2.31 \mathrm{~m}$. This analysis supports the hypothesis that the excessive IOD amplitude and 
(a) Near-surface u hPa

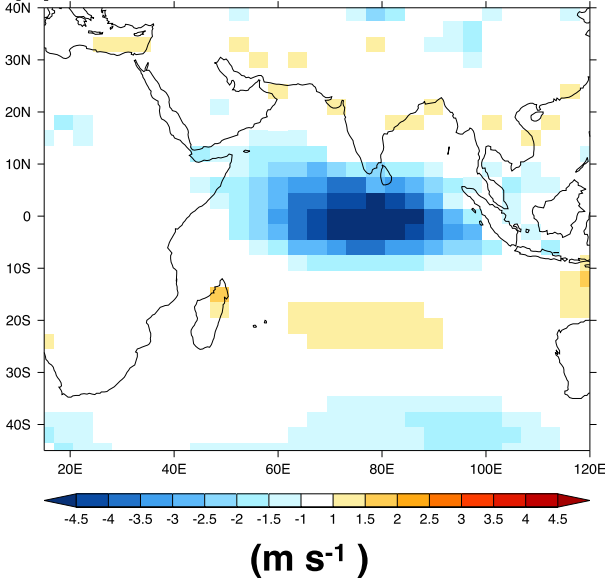

(c) Precipitation

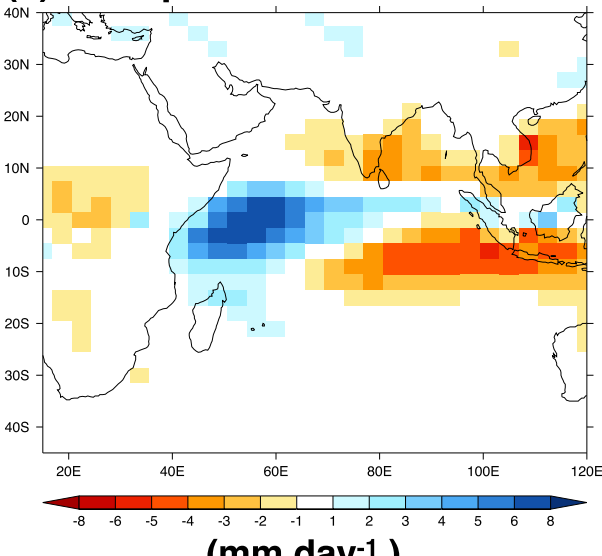

(mm day $\left.{ }^{-1}\right)$

(e) SST

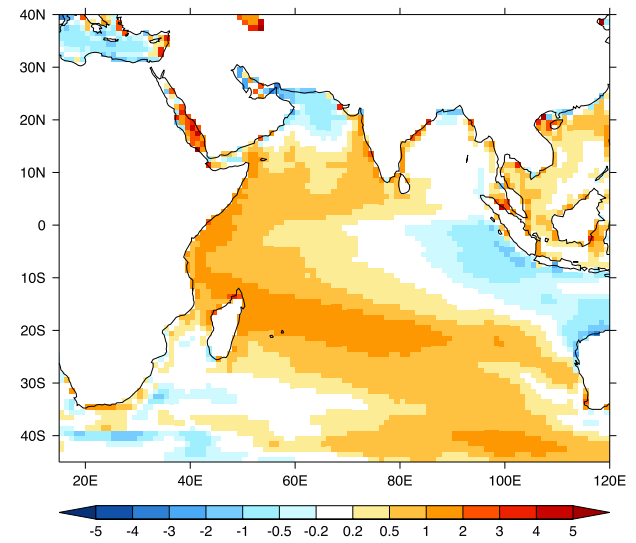

( $\left.{ }^{\circ} \mathrm{C}\right)$ (b) $\mathbf{u} 200 \mathrm{hPa}$

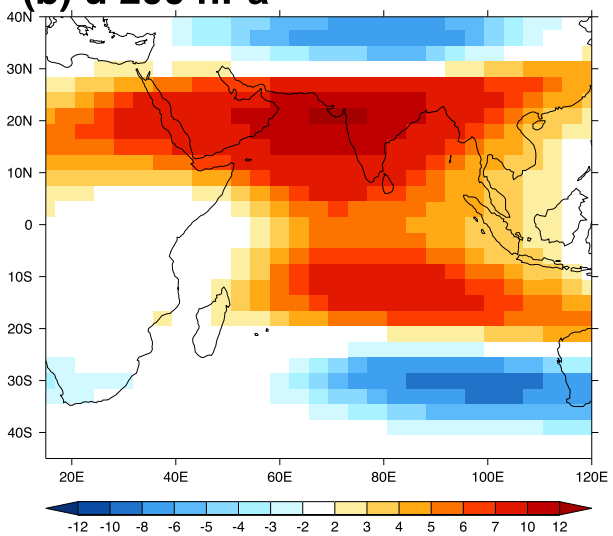

$\left(\mathrm{m} \mathrm{s}^{-1}\right)$
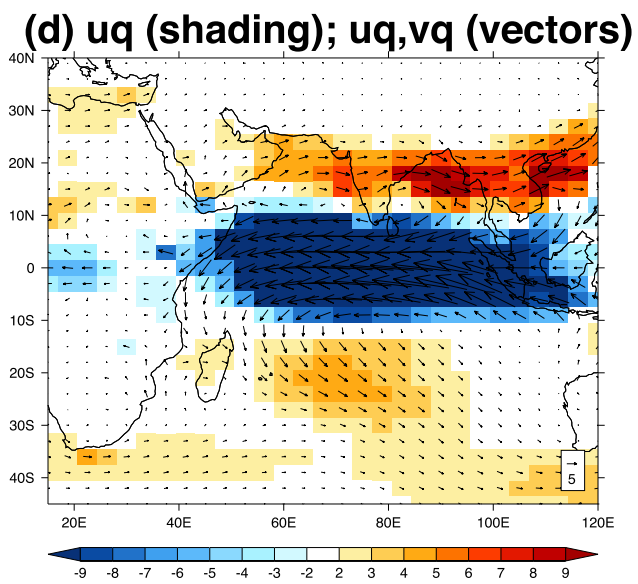

$\left(\mathrm{kg} \mathrm{m}^{-1} \mathrm{~s}^{-1}\right)$

\section{(f) $20^{\circ} \mathrm{C}$ isotherm depth}

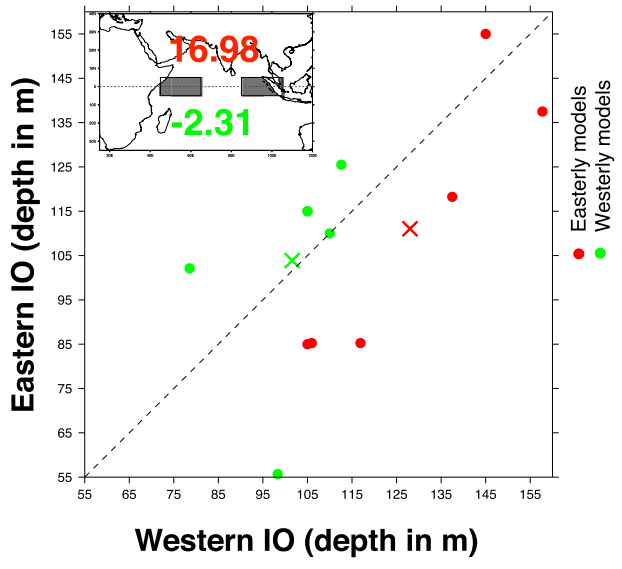

FIG. 8. Composite difference of six most easterly minus six most westerly CMIP models for mean (a) nearsurface zonal wind, (b) 200-hPa zonal wind, (c) precipitation, (d) 850-hPa moisture flux (vectors; $u q$ shading), (e) SST, and (f) $20^{\circ} \mathrm{C}$ isotherm depth in the eastern $\left(5^{\circ} \mathrm{S}-5^{\circ} \mathrm{N}, 85^{\circ}-105^{\circ} \mathrm{E}\right)$ vs western $\left(5^{\circ} \mathrm{S}-5^{\circ} \mathrm{N}, 45^{\circ}-65^{\circ} \mathrm{E}\right) \mathrm{IO}$ (boxes shown in insert map); for easterly (red) and westerly (green) models, the mean of the six models is indicated by the red and green crosses, respectively. The mean difference in $20^{\circ} \mathrm{C}$ isotherm depth between west and east is shown in the insert map for easterly models (red; $16.98 \mathrm{~m}$ ) and westerly models (green; $-2.31 \mathrm{~m}$ ). The easterly and westerly models used in the composites are labeled in Figs. $6 \mathrm{~b}$ and $7 \mathrm{~b}$ with the letters $\mathrm{E}$ and $\mathrm{W}$, respectively. Note that near-surface zonal wind data were not available for two of the six westerly models [CESM1(WACCM) and CESM1(CAM5)], so (a) is a composite of four models only. 
(a) Easterly Models +ve IOD

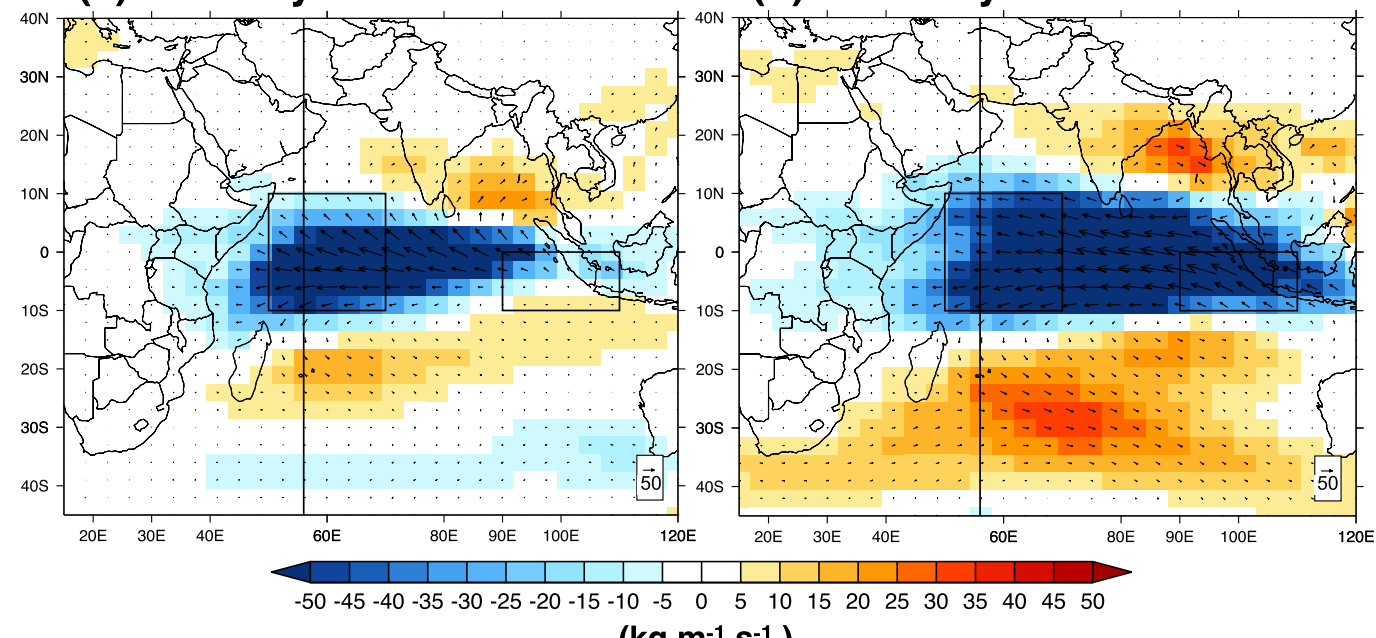

$\left(\mathrm{kg} \mathrm{m}^{-1} \mathrm{~s}^{-1}\right)$

FIG. 9. Composite anomaly of vertically integrated moisture flux (vectors; $u q$ shading) from positive IOD years for six (a) easterly EqIO models and (b) westerly EqIO models.

too-wet EASR in easterly models is a result of the Bjerknes feedback being too strong. The thermocline tilt toward the eastern IO in the easterly models is associated with the excessive easterly surface (Fig. 8a) and low-level zonal wind and an excessive west-east SST gradient (Fig. 8e). This also supports the findings of Cai and Cowan (2013), who show that models with the strongest thermocline-SST feedback also systematically exhibited the largest IOD amplitudes.

This composite analysis has shown that having an easterly mean-state bias in low-level winds in the equatorial IO leads to a weaker Walker circulation, warmer coastal SSTs, increased moisture advection into EA, a reduction of the SE trades, and an upward tilt in the thermocline toward the eastern IO. All of these basin-scale conditions are conducive to having wetter EASR resulting in an exacerbated wet bias during that season; the EA precipitation bias (averaged over the box $15^{\circ} \mathrm{S}-15^{\circ} \mathrm{N}, 30^{\circ}-60^{\circ} \mathrm{E}$ ) is more than doubled in the easterly models $\left(2.84 \mathrm{~mm} \mathrm{day}^{-1}\right)$ compared with the westerly models $\left(1.37 \mathrm{~mm}\right.$ day $^{-1}$; Table 3$)$.

To address how these biases affect the IOD teleconnection, similar analysis to that of Fig. 4 has been applied to the CMIP westerly and easterly models. Figure 9 shows the mean composite of vertically integrated moisture flux for positive IOD years from the six easterly and six westerly CMIP models (Table 3 ). Both sets of models show a clear advection of moisture across the equatorial IO toward EA. However, in the westerly models this is stronger and meridionally broader and there is some evidence of a split as it enters EA, with a weak equatorial dip as was observed in ERAInterim (Fig. 4a). The westerly models, with the closer-to-observed IO mean state, show stronger advection of moisture away from the African continent north and south of the equator, which also better matches ERA-Interim. This suggests that correctly simulating the low-level winds not only improves the EASR precipitation bias but also improves the structure of the vertically integrated advection of moisture over the continent (Fig. 9).

The moisture advection metric used in Fig. 5 has been applied to all CMIP and AMIP model simulations with available data ${ }^{6}$ and is shown in Fig. 10. This metric, which determines the impact of the IOD on moisture fluxes advected toward the EA coastline, shows the regression of vertically integrated zonal moisture flux $u q$ along each latitude band at $56^{\circ} \mathrm{E}$ (the vertical line marked in Fig. 9) onto the IOD index. As in Fig. 5, ERA-Interim shows strong peaks of moisture being advected into EA north and south of the equator with a local minimum or equatorial dip (black line in Fig. 10). The westerly models (thick green line in Fig. 10) are better able to capture this observed latitudinal structure compared with the easterly models (thick red line in Fig. 10), which exhibit a strong unimodal peak just south of the equator. All the individual AMIP and CMIP models are included in Fig. 10; it is clear that the mean moisture advection of AMIP models is weaker than that

\footnotetext{
${ }^{6}$ This analysis comprises 30 AMIP models and 42 CMIP models. In Figs. 6 and 748 CMIP models were used; however, specific humidity and SST data were only available for 42 of those, which are shown in Fig. 10.
} 


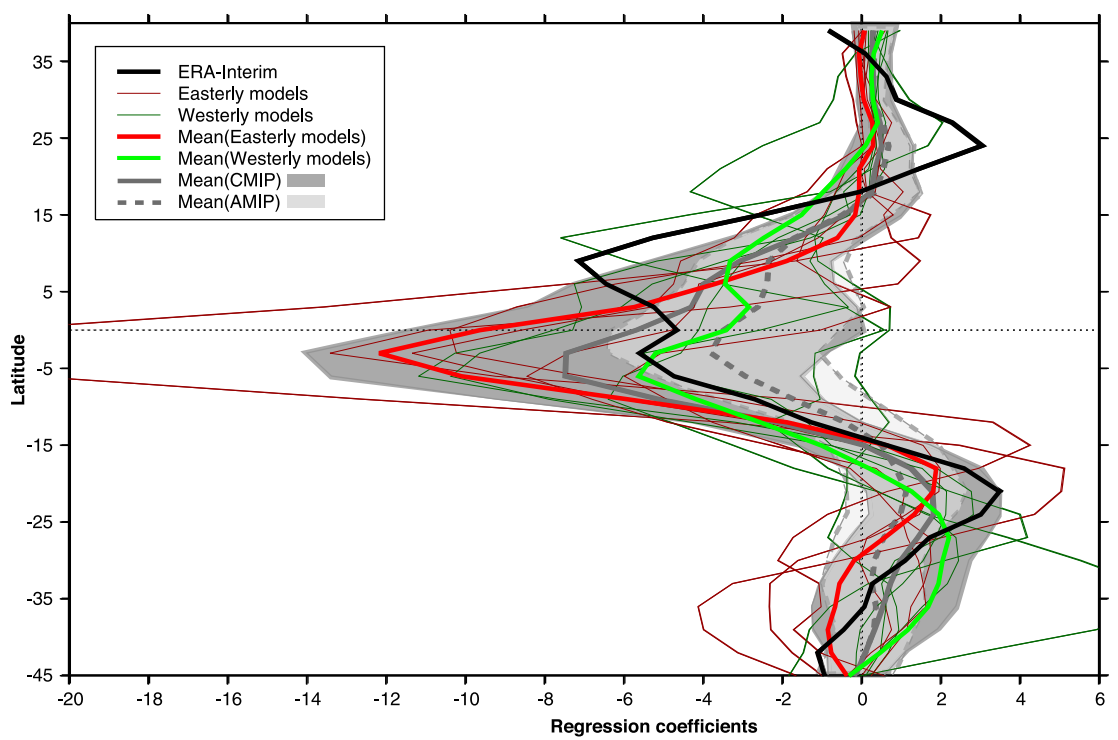

FIG. 10. Vertically integrated moisture flux $u q$ going along each latitude at $56^{\circ} \mathrm{E}$ regressed onto the IOD index. The thick black line represents ERA-Interim. The AMIP and CMIP means are represented by thick dashed and solid gray lines with plus and minus one standard deviation shown by the light and dark shading, respectively. The six easterly and westerly models that go into the composite analysis are represented by the thin red and green lines, with the easterly and westerly means represented by thick red and green lines, respectively.

of CMIP models (thick dashed and solid gray lines in Fig. 10).

\section{Discussion}

It has been shown that the overestimation in model precipitation over EA during OND is related to meanstate biases in the IO during that season. More specifically, those mean-state biases affect a model's ability to reproduce observed teleconnection patterns between the IOD and EASR. These results have been summarized schematically in Fig. 11. The anomalous SST pattern during a positive IOD results in anomalous easterly low-level flow across the equatorial IO Basin. In observations this reduces the mean-state equatorial westerlies to near zero (Figs. 3b and 11c). However, in models featuring mean-state easterlies at the equator (Fig. 11b), this strengthens the existing easterly flow (Figs. 3, 6, and (a) WESTERLY mean-state observations \& models

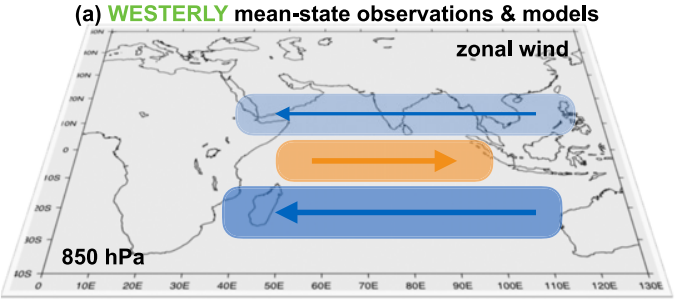

(b) EASTERLY mean-state models

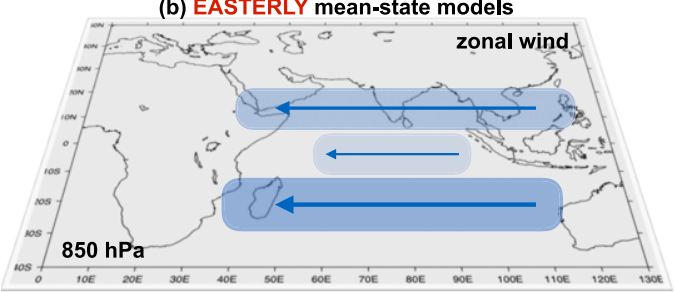

(c) +IOD with WESTERLY mean-state

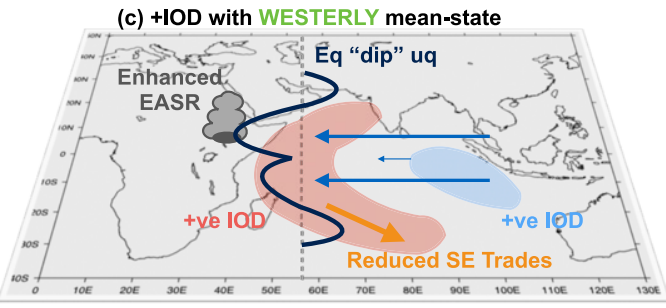

(d) +IOD with EASTERLY mean-state

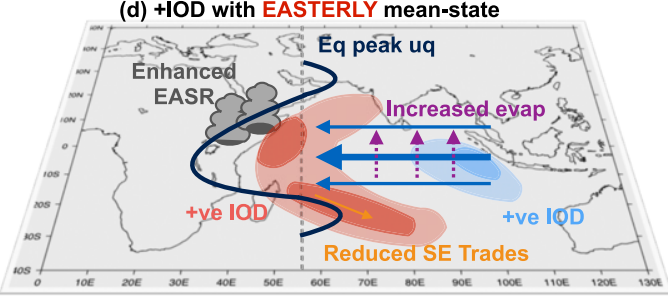

FIG. 11. (a),(b) Schematic representation of models with a westerly and easterly mean state, respectively.

(c),(d) Schematic representation of the response of a westerly and easterly model to a positive IOD. 
11d). Therefore, easterly mean-state models, with strengthened equatorial flow, have considerably more evaporation occurring at the equator than the westerly mean-state models. As well as having more moisture available through evaporation, the anomalous easterly surface wind stress causes upwelling of cold water in the eastern IO (Fig. 8f) that will further enhance the zonal SST gradient between west and east, strengthening the positive IOD pattern and further amplifying the easterly wind stress. This positive Bjerknes coupled feedback is likely to be stronger in the easterly mean-state models and will result in larger wet precipitation biases during the EASR (Figs. 7b and 11).

One interesting feature of the GCM analysis is that even models with observed westerly winds in the equatorial IO are able to maintain a wet bias in precipitation compared to GPCP (Figs. 6 and 7). This is likely due to a stronger cross-equatorial component of the low-level wind in the model mean state-and model positive IOD state-which brings excessive moisture along the EA coast from both the north and the south (Figs. 3 and 6).

To help understand why an equatorial dip exists in observed moisture advection into EA during a positive IOD, the analysis of Fig. 9 was repeated by month with October, November, and December separately (not shown). This revealed that during October the southern branch of moisture advection is favored and it is mainly during November, and more intensely during December, that the flow from the northeasterly monsoon winds has an influence and moisture is advected toward EA along the northern branch. The cross-equatorial component of the low-level wind along the EA coastline discussed above also has a monthly dependence: more moisture is advected from the south during October and from the north during November and December. This is true of both westerly and easterly mean-state models.

Section 3 showed that in the case of the MetUM, the atmosphere-only versions were able to capture the observed westerly mean-state in the equatorial IO whereas the coupled versions exhibited mean-state easterlies. To check if this is consistent for individual models within the CMIP ensemble, the analysis of Fig. 6 was repeated for paired models only (i.e., those with AMIP and CMIP equivalent). Six of the 22 paired models do show the same as the MetUM, with the coupled version exhibiting equatorial IO easterlies and the atmosphere-only version exhibiting mean-state westerlies. However, this is by no means systematic across models. Five of the 22 are the opposite way around, with westerlies in the CMIP model and easterlies in the AMIP model. For the remaining 11 model pairs, both AMIP and CMIP models exhibit low-level equatorial IO winds that flow in the same direction (five easterly pairs and six westerly pairs). Therefore, model pairs are distributed reasonably evenly between westerly and easterly flow in the equatorial IO with an easterly-to-westerly ratio of 9:15 and 14:10 for the AMIP and CMIP models, respectively. This confirms the hypothesis that the presence of an interactive ocean is not the only model characteristic that causes this mean-state IO bias. However, it does indicate that coupling is likely to exacerbate an existing bias through the positive Bjerknes-type coupled feedback discussed above.

\section{Conclusions}

It is well known that large-scale patterns of sea surface temperatures (SSTs) in the Pacific (e.g., Hoell and Funk 2014) and Indian (e.g., Bahaga et al. 2015) Oceans drive interannual variability in the East African short rains (EASR) from October to December (OND). However, the consensus from recent studies is that the EASR are more strongly modulated by the IO (e.g., Nicholson 2017), specifically the Indian Ocean dipole (IOD). Therefore, this study has focused on the role of the IOD in modulating the EASR on interannual time scales in a range of coupled and atmosphere-only global climate models, mostly drawn from CMIP5. Specifically, it has linked mean-state biases in the IO to deficiencies in representation of the short rains over EA and to the ability of a model to capture correctly the observed teleconnection patterns. This analysis has answered the questions presented at the start of this study.

\section{a. How is the wet bias over EA related to larger-scale mean-state biases in the $I O$, and are these consistent across models?}

In agreement with Yang et al. (2014), all models analyzed in this study (four MetUM and 30 AMIP and 48 CMIP simulations from CMIP5) exhibit a wet bias over EA. It is slightly reduced in atmosphere-only models compared with fully coupled atmosphere-ocean models (Figs. 2 and 7), but still present in both. It has also been shown that many of the models exhibit considerable biases in the low-level winds in the equatorial IO. The observed Walker cell over the IO during OND comprises low-level equatorial westerlies; however, half of the models examined actually exhibit mean easterlies at the equator during that season (Figs. 3 and 6). Those models that are unable to capture the observed equatorial westerlies in the IO are also responsible for the largest wet biases over EA during the short rains (Fig. 7b). It is important to note, however, that because of multiple models from individual modeling centers, and shared expertise, parameterizations, and code between modeling centers, not all of these models will be 
independent and therefore may share systematic biases (e.g., Abramowitz and Bishop 2015). The fact that half of the ensemble are unable to capture the observed westerlies over the IO suggests that this is indeed a widespread modeling issue. Furthermore, these biases are relevant to the findings of Tierney et al. (2015), who show that trends in global models toward a wetter EA in a warming climate can be attributed to a too-strong EASR, largely driven by a weakening of the Walker circulation. Further work is being carried out to understand the impacts of these basic-state biases on future projections of precipitation.

\section{$b$. What influence do such large-scale biases in the IO have on the interaction between the IOD and EASR?}

The analysis has shown that having the correct meanstate low-level winds over the IO during OND (i.e., westerlies rather than easterlies) was crucial to a model's ability to capture the correct latitudinal structure of moisture advection toward Africa during the IOD. In observations, the vertically integrated moisture advection during a positive IOD was shown to peak either side of the equator with a clear equatorial "dip." While all model simulations showed enhanced moisture advection toward the EA coast during a positive IOD, only models with mean-state westerlies in the IO, as in observations, were able to capture the observed equatorial dip (Figs. 5, 10, and 11).

\section{c. What is the role of ocean-atmosphere coupling?}

Determining the impact of air-sea coupling on how the IOD modulates the EASR on interannual time scales is by no means trivial. While coupling to a full dynamical ocean allows the two-way exchanges of heat, moisture, and momentum at the surface and large-scale oceanic modes of variability, such as ENSO and the IOD, to be explicitly resolved, it can also introduce significant mean-state biases in SST. Additionally, coupled feedbacks allow the atmosphere to respond to and generate SST anomalies that will have significant influence on the circulation. Atmosphere-only models were compared to their coupled counterparts in both MetUM and AMIP-CMIP simulations. In the MetUM, coupling was shown to introduce an SST bias that resembled a positive IOD (Fig. 2), and a change in the direction of the mean-state low-level wind in the equatorial IO from westerly to easterly (Fig. 3). These changes resulted in an excess of equatorial moisture being advected toward EA in the coupled model (Figs. 4 and 5) and a wetter EASR precipitation bias (Fig. 2).

However, the extension to the full CMIP ensemble of models showed that having an atmosphere-only model forced by observed SSTs did not always lead to correct mean-state wind in the equatorial IO. In fact, almost half the AMIP models exhibited mean-state easterlies (Fig. 6). Even when reducing the model ensemble to equivalent coupled and atmosphere-only pairs, only six of the 22 pairs showed similar results to the MetUM (with atmosphere only having westerly and coupled having easterly mean state equatorial wind). Additionally, the wet bias over EA was only slightly reduced in atmosphere-only models compared with coupled models (Fig. 7). Therefore, this analysis suggests that a model's mean state in the IO, that is, how well the strength of the large-scale IO Walker cell is represented, is a better indication for both a reduction in the EASR wet bias and its ability to capture the teleconnection between the IOD and the EASR. This is summarized in the schematic in Fig. 11.

Acknowledgments. This work has been conducted for the Natural Environment Research Council (NERC)Department for International Development (DFID)funded Improving Model Processes for African Climate (IMPALA) project (NE/M017222/1), as part of the Future Climate for Africa (FCFA) programme. We acknowledge the World Climate Research Programme's Working Group on Coupled Modelling, which is responsible for CMIP, and we thank the climate modeling groups (listed in Table 2) for making available their model output.

\section{REFERENCES}

Abramowitz, G., and C. H. Bishop, 2015: Climate model dependence and the ensemble dependence transformation of CMIP projections. J. Climate, 28, 2332-2348, https://doi.org/ 10.1175/JCLI-D-14-00364.1.

Anyah, R. O., and W. Qiu, 2012: Characteristic 20th and 21st century precipitation and temperature patterns and changes over the Greater Horn of Africa. Int. J. Climatol., 32, 347-363, https://doi.org/10.1002/joc.2270.

Bahaga, T. K., G. Mengistu Tsidu, F. Kucharski, and G. T. Diro, 2015: Potential predictability of the sea-surface temperature forced equatorial East African short rains interannual variability in the 20th century. Quart. J. Roy. Meteor. Soc., 141, 1626, https://doi.org/10.1002/qj.2338.

Bergonzini, L., Y. Richard, L. Petit, and P. Camberlin, 2004: Zonal circulations over the Indian and Pacific Oceans and the level of Lakes Victoria and Tanganyika. Int. J. Climatol., 24, 16131624, https://doi.org/10.1002/joc.1089.

Black, E., J. Slingo, and K. R. Sperber, 2003: An observational study of the relationship between excessively strong short rains in coastal East Africa and Indian Ocean SST. Mon. Wea. Rev., 131, 74-94, https://doi.org/10.1175/1520-0493(2003)131<0074: AOSOTR $>2.0 . \mathrm{CO} ; 2$

Bollasina, M. A., and Y. Ming, 2013: The general circulation model precipitation bias over the southwestern equatorial Indian Ocean and its implications for simulating the South Asian monsoon. Climate Dyn., 40, 823-838, https://doi.org/10.1007/ s00382-012-1347-7. 
Bowden, J. H., and F. H. M. Semazzi, 2007: Empirical analysis of intraseasonal climate variability over the Greater Horn of Africa. J. Climate, 20, 5715-5731, https://doi.org/10.1175/ 2007JCLI1587.1.

Cai, W., and T. Cowan, 2013: Why is the amplitude of the Indian Ocean dipole overly large in CMIP3 and CMIP5 climate models? Geophys. Res. Lett., 40, 1200-1205, https://doi.org/ $10.1002 /$ grl.50208.

——, X.-T. Zheng, E. Weller, M. Collins, T. Cowan, M. Lengaigne, W. Yu, and T. Yamagata, 2013: Projected response of the Indian Ocean dipole to greenhouse warming. Nat. Geosci., 6, 999-1007, https://doi.org/10.1038/ ngeo2009.

Camberlin, P., and J. G. Wairoto, 1997: Intraseasonal wind anomalies related to wet and dry spells during the "long" and "short" rainy seasons in Kenya. Theor. Appl. Climatol., 58, 57-69, https://doi.org/10.1007/BF00867432.

Compo, G. P., and Coauthors, 2011: The Twentieth Century Reanalysis project. Quart. J. Roy. Meteor. Soc., 137, 1-28, https:// doi.org/10.1002/qj.776.

Dee, D. P., and Coauthors, 2011: The ERA-Interim reanalysis: Configuration and performance of the data assimilation system. Quart. J. Roy. Meteor. Soc., 137, 553-597, https://doi.org/ 10.1002/qj.828.

Dezfuli, A. K., and S. E. Nicholson, 2013: The relationship of rainfall variability in western equatorial Africa to the tropical oceans and atmospheric circulation. Part II: The boreal autumn. J. Climate, 26, 66-84, https://doi.org/10.1175/ JCLI-D-11-00686.1.

FEWS NET, 2011: East Africa: Past year one of the driest on record in the eastern Horn. Famine Early Warning System Network Tech. Rep., 1 pp., http://reliefweb.int/sites/reliefweb. int/files/resources/FEWS\%2520NET\%2520EA_Historical\% 2520drought\%2520context_061411.pdf.

Goddard, L., and N. E. Graham, 1999: Importance of the Indian Ocean for simulating rainfall anomalies over eastern and southern Africa. J. Geophys. Res., 104, 19 099-19116, https:// doi.org/10.1029/1999JD900326.

Hastenrath, S., 2000: Zonal circulations over the equatorial Indian Ocean. J. Climate, 13, 2746-2756, https://doi.org/10.1175/ 1520-0442(2000)013<2746:ZCOTEI >2.0.CO;2.

—, A. Nicklis, and L. Greischar, 1993: Atmospherichydrospheric mechanisms of climate anomalies in the western equatorial Indian Ocean. J. Geophys. Res., 98, 20 219-20 235, https://doi.org/10.1029/93JC02330.

_ D. Polzin, and C. Mutai, 2011: Circulation mechanisms of Kenya rainfall anomalies. J. Climate, 24, 404-412, https:// doi.org/10.1175/2010JCLI3599.1.

Hoell, A., and C. Funk, 2014: Indo-Pacific sea surface temperature influences on failed consecutive rainy seasons over eastern Africa. Climate Dyn., 43, 1645-1660, https://doi.org/10.1007/ s00382-013-1991-6.

Huffman, G. J., R. A. Alder, D. T. Bolvin, and G. Gu, 2009: Improving the global precipitation record: GPCP version 2.1 . Geophys. Res. Lett., 36, L17808, https://doi.org/10.1029/ 2009GL040000.

Kistler, R., and Coauthors, 2001: The NCEP-NCAR 50-year reanalysis: Monthly means CD-ROM and documentation. Bull. Amer. Meteor. Soc., 82, 247-267, https://doi.org/ 10.1175/1520-0477(2001)082<0247:TNNYRM>2.3.CO;2.

Li, C., Y. Chai, L. Yang, and H. Li, 2016: Spatio-temporal distribution of flood disasters and analysis of influencing factors in
Africa. Nat. Hazards, 82, 721-731, https://doi.org/10.1007/ s11069-016-2181-8.

Li, G., and S.-P. Xie, 2014: Tropical biases in CMIP5 multimodel ensemble: The excessive equatorial Pacific cold tongue and double ITCZ problems. J. Climate, 27, 1765-1780, https:// doi.org/10.1175/JCLI-D-13-00337.1.

,-- , and Y. Du, 2015: Monsoon-induced biases of climate models over the tropical Indian Ocean. J. Climate, 28, 30583072, https://doi.org/10.1175/JCLI-D-14-00740.1.

Liebmann, B., and Coauthors, 2014: Understanding recent eastern Horn of Africa rainfall variability and change. J. Climate, 27, 8630-8645, https://doi.org/10.1175/JCLI-D-13-00714.1.

Madec, G., 2008: NEMO ocean engine. IPSL Note du Pôle de modélisation 27, 386 pp., https://www.nemo-ocean.eu/wp-content/ uploads/NEMO_book.pdf.

Manatsa, D., Y. Morioka, S. K. Behera, C. H. Matarira, and T. Yamagata, 2014: Impact of Mascarene high variability on the East African 'short rains'. Climate Dyn., 42, 1259-1274, https://doi.org/10.1007/s00382-013-1848-z.

Moron, V., A. W. Robertson, M. N. Ward, and P. Camberlin, 2007: Spatial coherence of tropical rainfall at the regional scale. J. Climate, 20, 5244-5263, https://doi.org/10.1175/ 2007JCLI1623.1.

Mutai, C., D. Polzin, and S. Hastenrath, 2012: Diagnosing Kenya rainfall in boreal autumn: Further exploration. J. Climate, 25, 4323-4329, https://doi.org/10.1175/JCLI-D-11-00414.1.

Nakamura, N., H. Kayanne, H. Iijima, T. R. McClanahan, S. K. Behera, and T. Yamagata, 2011: Footprints of IOD and ENSO in the Kenyan coral record. Geophys. Res. Lett., 38 , L24708, https://doi.org/10.1029/2011GL049877.

Nicholson, S. E., 2014: A detailed look at the recent drought situation in the Greater Horn of Africa. J. Arid Environ., 103, 7179, https://doi.org/10.1016/j.jaridenv.2013.12.003.

_ 2015: Long-term variability of the East African 'short rains' and its links to large-scale factors. Int. J. Climatol., 35 , 39793990, https://doi.org/10.1002/joc.4259.

_ 2016: An analysis of recent rainfall conditions in eastern Africa. Int. J. Climatol., 36, 526-532, https://doi.org/10.1002/joc.4358.

_ 2017: Climate and climatic variability of rainfall over eastern Africa. Rev. Geophys., 55, 590-635, https://doi.org/10.1002/ 2016RG000544.

—_, and J. Kim, 1997: The relationship of the El Niño-Southern Oscillation to African rainfall. Int. J. Climatol., 17, 117-135, https://doi.org/10.1002/(SICI)1097-0088(199702)17:2<117:: AID-JOC84>3.0.CO;2-O.

— , and J. C. Selato, 2000: The influence of La Niña on African rainfall. Int. J. Climatol., 20, 1761-1776, https://doi.org/ 10.1002/1097-0088(20001130)20:14<1761::AID-JOC580>3.0. $\mathrm{CO} ; 2-\mathrm{W}$.

Rayner, N. A., D. E. Parker, E. B. Horton, C. K. Folland, L. V. Alexander, D. P. Rowell, E. C. Kent, and A. Kaplan, 2003: Global analyses of sea surface temperature, sea ice, and night marine air temperature since the late nineteenth century. J. Geophys. Res., 108, 4407, https://doi.org/10.1029/ 2002JD002670.

Reynolds, R. W., T. M. Smith, C. Liu, D. B. Chelton, K. S. Casey, and M. G. Schlax, 2007: Daily high-resolution-blended analyses for sea surface temperature. J. Climate, 20, 5473-5496, https://doi.org/10.1175/2007JCLI1824.1.

Rowell, D. P., 2013: Simulating SST teleconnections to Africa: What is the state of the art? J. Climate, 26, 5397-5418, https:// doi.org/10.1175/JCLI-D-12-00761.1. 
Saji, N. H., B. N. Goswami, P. N. Vinayachandran, and T. Yamagata, 1999: A dipole model in the tropical Indian Ocean. Nature, 401, 360-363, https://doi.org/10.1038/43854.

Sperber, K. R., H. Annamalai, I.-S. Kang, A. Kitoh, A. Moise, A. Turner, B. Wang, and T. Zhou, 2013: The Asian summer monsoon: An intercomparison of CMIP5 vs. CMIP3 simulations of the late 20th century. Climate Dyn., 41, 2711-2744, https://doi.org/10.1007/s00382-012-1607-6.

Taylor, K. E., R. J. Stouffer, and G. A. Meehl, 2012: An overview of CMIP5 and the experiment design. Bull. Amer. Meteor. Soc., 93, 485-498, https://doi.org/10.1175/BAMS-D-11-00094.1.

Tierney, J. E., C. C. Ummenhofer, and P. B. deMenocal, 2015: Past and future rainfall in the Horn of Africa. Sci. Adv., $\mathbf{1}$ e1500682, https://doi.org/10.1126/sciadv.1500682.

Valcke, S., 2013: The OASIS3 coupler: A European climate modelling community software. Geosci. Model Dev., 6, 373388, https://doi.org/10.5194/gmd-6-373-2013.

Walters, D. N., and Coauthors, 2011: The Met Office Unified Model Global Atmosphere 3.0/3.1 and JULES Global Land
3.0/3.1 configurations. Geosci. Model Dev., 4, 919-941, https:// doi.org/10.5194/gmd-4-919-2011.

Wang, C., L. Zhang, S.-K. Lee, L. Wu, and C. R. Mechoso, 2014: A global perspective on CMIP5 climate model biases. Nat. Climate Change, 4, 201-205, https://doi.org/10.1038/ nclimate2118.

Williams, K. D., and Coauthors, 2015: The Met Office Global Coupled Model 2.0 (GC2) configuration. Geosci. Model Dev., 8, 1509-1524, https://doi.org/10.5194/gmd-8-1509-2015.

Yang, W., R. Seager, M. A. Cane, and B. Lyon, 2014: The East African long rains in observations and models. J. Climate, 27, 7185-7202, https://doi.org/10.1175/JCLI-D-13-00447.1.

,,,--- and $-2015 \mathrm{a}$ : The annual cycle of East African precipitation. J. Climate, 28, 2385-2404, https://doi.org/ 10.1175/JCLI-D-14-00484.1.

_ — _ - and $-2015 \mathrm{~b}$ : The rainfall annual cycle bias over East Africa in CMIP5 coupled climate models. J. Climate, 28, 9789-9802, https://doi.org/10.1175/ JCLI-D-15-0323.1. 